\title{
Bone Regeneration Induced by Strontium Folate Loaded Biohybrid Scaffolds
}

\author{
Marcela Martín-del-Campo ${ }^{1, *(\mathbb{D}}$, José G. Sampedro ${ }^{2}(0)$, María Lisseth Flores-Cedillo ${ }^{3}(0$, \\ Raul Rosales-Ibañez ${ }^{4}$ and Luis Rojo ${ }^{1,5, * \mathbb{D}}$ \\ 1 Departamento de Biomateriales, Instituto de Ciencia y Tecnología de Polímeros, CSIC, 28006 Madrid, Spain \\ 2 Instituto de Física, Universidad Autónoma de San Luis Potosí, Manuel Nava 6, Zona Universitaria, San Luis \\ Potosí C.P. 78290, S.L.P., Mexico; sampedro@dec1.ifisica.uaslp.mx \\ 3 División de Ingeniería Industrial, Instituto Tecnológico Superior de San Luis Potosí, Capital, Carretera 57 \\ Tramo Qro-SLP Km 189+100 No. 6501, Deleg, Villa de Pozos, San Luis Potosí C.P. 78421, S.L.P., Mexico; \\ maria.flores@tecsuperiorslp.edu.mx \\ 4 Escuela de Etudios Superiores, Iztacala, Universidad Nacional Autónoma de Mexico, UNAM, \\ Tlalnepantla 54090, Mexico; rosales_ibanez@unam.mx \\ 5 Consorcio Centro de Investigación Biomedica en red, CIBER-BBN, 28029 Madrid, Spain \\ * Correspondence: mar_tin53@hotmail.com (M.M.-d.-C.); rojodelolmo@ictp.csic.es (L.R.)
}

Academic Editor: Margit Schulze

Received: 6 March 2019; Accepted: 26 April 2019; Published: 27 April 2019

\begin{abstract}
Nowadays, regenerative medicine has paid special attention to research (in vitro and in vivo) related to bone regeneration, specifically in the treatment of bone fractures or skeletal defects, which is rising worldwide and is continually demanding new developments in the use of stem cells, growth factors, membranes and scaffolds based on novel nanomaterials, and their applications in patients by using advanced tools from molecular biology and tissue engineering. Strontium ( $\mathrm{Sr}$ ) is an element that has been investigated in recent years for its participation in the process of remodeling and bone formation. Based on these antecedents, this is a review about the Strontium Folate (SrFO), a recently developed non-protein based bone-promoting agent with interest in medical and pharmaceutical fields due to its improved features in comparison to current therapies for bone diseases.
\end{abstract}

Keywords: bone regeneration; musculoskeletal defects; strontium folate

\section{Introduction}

The rise in the average age of the population has led to a steady increase in the number of musculoskeletal conditions and in particular of cartilage and bone surgical procedures in the last years [1,2]. Therefore, the development of alternative materials and strategies in bone replacement therapies has attracted high interest. Above a critical size, bone defects are not repaired by the self-healing system of the tissue; thus, an osteoconductive and osteoinductive device (or scaffold) is usually required in order to regenerate the lost tissue. The scaffold must be composed of materials that stimulate and favor the formation of new bone tissue as well as to be structurally stable during the process of cell growth and expansion [3]. In this regard, autografts are still amply considered as the "gold standard"; however, they have many drawbacks such as limited availability and morbidity of the donor site $[4,5]$. Alternatively, a proper scaffold made of a given biomaterial would be desirable both to fill the defect and to act as a reservoir for growth factors and/or cells $[6,7]$.

High biocompatibility and proper physical-chemistry of the surface are the most essential requirements in biomaterials intended to be used in scaffold construction $[6,7]$. Nonetheless, several others important criteria must also be taken into account; these are cell adhesion, proliferation and 
differentiation, biodegradability, mechanical efficiency (in a given specific application), bio-conductivity, bioactivity, suitability to the sterilizing procedure, stability during storage, and finally, high cost-effectiveness ratio [6,7]. Polymers are usually good candidates despite only few are those displaying most of the characteristics required for their use as bone substitutes [8]. Additionally, some polymers may generate inflammation (an immunological reaction to foreign body). Such reaction usually leads to the failure of the engineered product, and thus severely restricting the use of these polymers as scaffolds [9]. To date, unfortunately, there are no materials with the desired characteristics to construct an optimal scaffold, i.e., with the properties required to generate new bone tissue [10]. Currently, the employment of different types of technologies as well as the generation of new polymeric synthetic scaffolds has become an attractive option in order to overcome the drawbacks of synthetic and natural polymers [11]. Furthermore, the inclusion of metal ions and trace elements essential in bone formation may be considered in scaffold synthesis, e.g., calcium $\left(\mathrm{Ca}^{2+}\right)$, magnesium $\left(\mathrm{Mg}^{2+}\right)$, and phosphate ions $\left(\mathrm{PO}_{4}{ }^{3-}\right)$, while metallic trace elements when incorporated into bone structure promote both osteogenesis and angiogenesis thus enhancing bone remodeling and the repair process [12]. Notably, amongst the metallic trace elements, $\mathrm{Sr}$ has been extensively studied [10]. Sr, because of its resemblance (in charge and size) to calcium (Ca), has the ability to substitute $\mathrm{Ca}$ ions in the apatite structure $[10,13]$. Jimenez et al. reported that $\mathrm{Sr}$ induces human stem cell differentiation towards cartilage and bone like phenotypes in vitro. Thus, biomaterials containing Sr would enhanced their performance both in vitro and in vivo, that is, by inducing the formation of new bone and cartilage tissues while inhibiting tissue resorption [14].

Certainly, Sr stimulates the activity of osteoblasts while inhibiting the activity of osteoclasts [14]. In this regard, Place et al. evaluated the osteogenic potential and showed that Sr may improve osteogenic differentiation [15]. Accordingly, some authors performed the transplantation of strontium-based systems in bone defects [16,17]; computed tomography and histological analysis showed a significant improvement in bone formation in vivo, i.e., the amount of both mature and remodeled bone substantially increased and extracellular matrix accumulated [16,17]. Further studies showed that $\mathrm{Sr}$ increased the expression of $\beta$-catenin in the newly formed bone, and such an effect was expected to occur either in vitro and in vivo, e.g., a significant osteogenic differentiation of mesenchymal stem cells (MSCs) was expected when in the presence of Sr, and consequently, the formation of bone [15-18]. Additional studies suggested the incorporation of $\mathrm{Sr}$ ions in bone substitutes but were also shown to be effective in the stimulation of the proliferation and differentiation of bone MSCs, osteoblasts, and periodontal ligament cells in vivo [19-21]. Hence, a three-dimensional (3D) biohybrid scaffold based on calcium phosphate and a bio-active derivative of Vitamin-B and Sr (Strontium Folate, SrFO) was developed. This device induced the healing of critical-sized cranial defects in rats using human dental pulp stem cells (HDPSCs) without the addition of exogenous growth factors. The seeded HDPSCs proliferated and differentiated, hence developing a bone regenerative capacity. This seems to be a novel tissue engineering approach to regenerate critical sized bone defects in vivo [16]. Due to the high potential of SrFO in bone regenerative medicine, currently, new regenerative devices have been developed based on SrFO. Very recently, Xu et al. demonstrated that strontium folic acid derivatives promote in vitro the osteogenic differentiation of MSCs shortly after addition; especially in the long term. Particularly, such derivatives improved significantly bone formation around the bio-functional orthopedic implants in vivo, which was highly evident at late stages [17].

\section{Factors Involved in the Repair of Bone Tissue}

The process of bone tissue repair involves a complex cascade of biological events controlled by numerous cytokines and growth factors (GF). These factors provide the signals that induce the migration of osteoprogenitor cells and promote the subsequent differentiation and proliferation in cell lineages, tissue revascularization, and production of the extracellular matrix [22]. Therefore, the inclusion of growth factors, as well as bone morphogenetic proteins (BMPs), and fibroblastic growth factors (FGFs) in scaffolds seeded with stem cells have been demonstrated to be important in the effectiveness of the 
regenerative process [23]. However the use of these GF in clinical applications has been restricted due to their limited availability in terms of price, shelf life during storage and manipulation, and the short time in effectiveness after their application due to hydrolysis, neutralization, and degradation.

Bone tissue consists mainly of the protein collagen $(\sim 90 \%)$, and of cells with a role in bone formation and growth, repair and synthesis of the extra cellular matrix $[23,24]$. The matrix is formed by a small binding integrin-linked to glycoprotein $\mathrm{N}$. The sibiling protein family is formed by five members: (a) osteopontin (OPN), (b) fosfoglycoprotein of the extracellular matrix (MEPE), (c) bone sialoprotein (BSP), (d) dentin matrix protein 1 (DMP1), and (e) dentin sialophosphoroprotein (DSPP). The members of the family share some structural characteristics, namely: collagen binding domain, HA binding domain, and arginine-glycine-aspartic acid (RGD) cell binding domain [23]. Undoubtedly, these proteins have an important role in bone development, i.e., facilitating cell adhesion, nucleation, and mineral maturation. Nonetheless, researchers are still trying to elucidate the exact role of each protein in natural bone development $[24,25]$.

Tumor necrosis factor $\alpha(\mathrm{TNF} \alpha)$ is one of the most potent osteoclastogenic cytokines. TNF $\alpha$ stimulates bone resorption in vitro and in vivo by increasing the proliferation and differentiation of osteoclast precursors [26,27]. In contrast, OPG can reverse the loss of bone in animal models of sex-steroid insufficiency and glucocorticoid-induced osteoporosis, rheumatoid arthritis, multiple myeloma, and metastatic bone disease [28]. Since OPG directly counteracts all RANKL mediated activities through RANK, therefore the RANKL/OPG ratio is determinant in bone mass and integrity of the skeleton. In contrast, the increased expression of RANKL by tumor cells and tumor-mediated increase of RANKL/OPG ratio in bone microenvironment may be observed in myelomas and in osteolytic metastasis in prostate and breast cancer [27,29-33].

\section{Dental Pulp Stem Cells and Osteogenic Differentiation}

Stem cells are generally defined as clonogenic cells capable of self-renewal; these are non-specialized cells that renew by cell division with the remarkable ability to differentiate to a specific cellular type [34-36]. Since stem cells are able to repair or replace damaged tissues, thus leading to recover from illness (or injury), they have been employed successfully. Therefore, the number of patients subjected to tissue transplants, plus patient receptors of stem cell therapy, has increased recently [11].

Dental pulp has been considered an excellent source of adult stem cells, even better than bone marrow. Hence, research has been focused to test its therapeutic application [3,37], e.g., in tissue engineering, where numerous laboratories have assessed its potential in pre-clinical applications in the regeneration of tissues [33]. Importantly, adult dental pulp tissue does contain multipotential stem cells and under given conditions, the derived pulp stem cell cultures may develop to specialized odontoblasts-like cells competent to form mineralized nodules in vitro [34]. In this regard, dental tissues are easily accessible during routine clinical practice, namely upon tooth extraction; thus providing a source of trustworthy stem cells, ideal for development and testing of new therapies [38]. Technically, stem cells are isolated from pulp tissues degraded from the selection of a unique colony (Figure 1). These stems cells usually exhibit high proliferation and clonogenic properties; they also exhibit the typical immuno-reactivity profile of bone marrow stromal cells [34]. Furthermore, the osteogenic cultures are able to synthesize fibers, similar to bone tissue, thus forming a densely mineralized matrix. These so generated lamellar fibrous bone tissue usually tend to contain osteocytes, after transplantation into living organisms [39].

Studies in engineering bone tissue have demonstrated the potential of DPSCs when in combination with a 3D matrix. Mineralization and hard tissue formation are achieved by partially developed hematopoietic bone tissue [40]. Similar results have been obtained upon implantation of manufactured constructs consisted of DPSCs embedded in scaffolds [16,41]. It is worth to note that this strategy produces a highly mineralized tissue. Thus, generating a deep interest and encouraging the use of DPSCs in clinical bone tissue replacement therapies [41]. 
A)

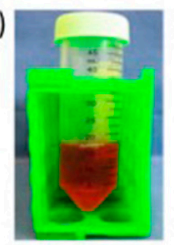

B)

D)

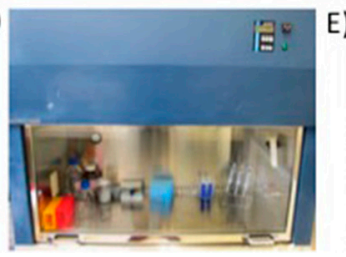

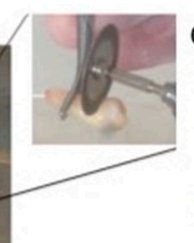

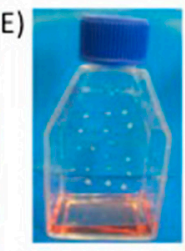

C)
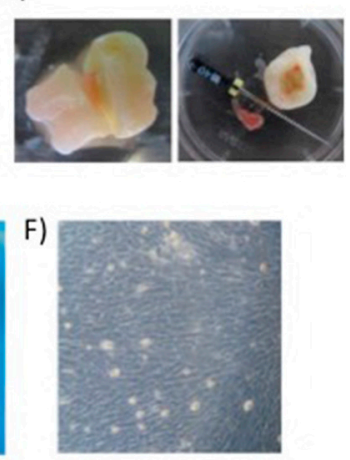

Figure 1. Procedure for culture and proliferation of dental pulp stem cells (DPSCs) used in bone tissue engineering as reported in Martin-del-Campo et al. (A) Dental organs stored in culture medium and antibiotics. (B) Segmentation of dental organs. (C) Extraction of dental pulp. (D) Laminar flow hood for cellular handling. (E) Generated cellular nodules from cells. (F) Expanded Dental Pulp Mesenchymal Stem Cells [16].

\section{The Use of Strontium in Bone Repair}

Strontium is an element that has an approximate volume of distribution of $11 / \mathrm{kg}$. The Sr binding capacity to human plasma proteins is low $(\sim 25 \%)$, but display high affinity for bone tissues. Studies showed that $\mathrm{Sr}$ elimination is performed by the kidneys and gastrointestinal tract, but independent on time or dose. The effective half-life is $\sim 60 \mathrm{~h}$. Sr plasma clearance is achieved at $12 \mathrm{~mL} / \mathrm{min}(\mathrm{CV} 22 \%)$, while its renal clearance is achieved at $7 \mathrm{~mL} / \mathrm{min}(\mathrm{CV} 28 \%)$ [42].

It has been described that $\mathrm{Sr}$ is adsorbed on the surface of bone mineral, instead of replacing Ca ions; this favors its rapid elimination. Nonetheless, Sr has a particular ability to cause catabolic and anabolic effects during bone remodeling through the induction of prostaglandin synthesis and expression of cyclooxygenase, which increases the differentiation to osteoblasts from mesenchymal stem cells (MSCs). Peng et al. showed that Sr could increase bone osteoblastic differentiation in vivo, and participate in the process of MSCs differentiation in vitro [43]. However, the mechanism by which $\mathrm{Sr}$ affects the signaling pathways leading to osteogenic differentiation in human MSCs resulting in bone formation is unknown [44].

According to in vivo experimental models, $\mathrm{Sr}$ is able induce anabolic events promoting bone formation; however, further experimental and clinical analyses on the associated pathways are required to clarify its effects at the molecular level [45]. Furthermore, in a postmenopausal osteoporosis animal model, the long administration of Sr prevented the trabecular loss of bone induced by estrogen deficiency, probably promoting bone formation by increasing bone mineral density and preventing its resorption [45]. In this regard, experimental results showed that $\mathrm{Sr}$ administration increases the number of osteoblasts, decreases the number of osteoclasts, and promotes matrix formation. Notably, besides the effect on bone cells population and bone micro-architecture, Sr increases the mechanical resistance of bone through changes in the properties of bone matrix [14,46].

Fernández-Murga et al. performed a global genomic study on the effect of different $\mathrm{Sr}$ compounds and a calcium salt in pre-osteoblasts cultures, thus obtaining information on genes and the signaling pathways involved in osteogenesis. Importantly, strontium induces the maturation process of pre-osteoblasts after 21 days of treatment, nonetheless the most notable changes occurs immediately at cellular level on gene expression and activation of signaling pathways related to osteogenic events. Successive waves of changes in gene expression pattern occurs within $0-7$ days, which seems to be required to initiate the differentiation of pre-osteoblasts to a mineralizing phenotype. The expression of many genes related to regulation of transcription, metabolic processes and transport of molecules change in this first phase of the maturation process [46]. In this regard, phosphorylation-dephosphorylation of proteins was shown to be the main biochemical event in this 
initial short time span; phosphorylation-dephosphorylation of proteins is well known to be involved in the regulation of metabolic pathways as well as in other important cellular processes. For instance, Wnt and NFAT signaling pathways were shown to be involved in the maturation of osteoblasts $[47,48]$, as both Wnt/ $\beta$-catenin and NFAT pathways behaved as potent osteoprogenitors inducing gene expression changes in short times. In contrast, cell cultures treated with strontium showed no activation of these pathways at day 21. Hence, once confluence is reached, that is, when increased ALP activity and the deposit of mineralized matrix are observed, the cells enter into the differentiation phase [46]. This phase is characterized by an increase in the formation of bone matrix, which is associated to the change in expression of 147 genes. In addition, cellular processes related to the energy state of the cell increases remarkably in this second phase, namely carbohydrate metabolism (glucose and other carbohydrates) including gluconeogenesis [46].

Overall, Sr is currently known to stimulate osteoblasts promoting osteogenesis both in vivo and in vitro, while conversely, Sr down-modulates function in osteoclast preventing bone resorption $[49,50]$. The Sr anabolic effects involve Ca receptors leading to improve: preosteoblast replication, osteoblasts differentiation, synthesis of collagen type I, and mineralization of bone matrix [18,51]. Sr replaces Ca in the metabolism and functions of osteoblasts and also enhances osteogenesis inducing osteoblast division while preventing osteoclast resorption. In addition, Sr enhances osteoblasts differentiation to osteocytes [52]. In this regard, osteocytes modulate the function of both osteoblasts and osteoclasts, thus displaying a role in the uncoupling of bone turnover by producing paracrine signals triggered by the mechanical load [10,53-55].

Similarly to $\mathrm{Ca}, \mathrm{Sr}$ is also absorbed in the intestine and finally distributed between three main compartments, namely in plasma and extracellular fluids, soft tissues, and particularly in bones. Notably, alteration of the $\mathrm{Sr} / \mathrm{Ca}$ and $\mathrm{Sr} / \mathrm{P}$ ratios have been linked to skeletal deformities [56]. Pasqualetti et al. stated that bone deformities and other disorders occur at low $\mathrm{Ca} / \mathrm{Sr}$ ratios, thus resulting in a slower $\mathrm{Ca}$ uptake into bone tissue hence facilitating the replacement of Ca by other elements. The Sr usually acts replacing $\mathrm{Ca}$, as it displays physical and chemical similarity to $\mathrm{Ca}$. Sr, once ingested, become present in all body tissues; nonetheless, about $90 \%$ of it accumulates in the bones [57]. Sr is slowly excreted by the body, and as suggested by Polak-Juszczak et al. this seems to be the cause of the high Sr and low Ca concentration resulting in low $\mathrm{Ca} / \mathrm{Sr}$ ratio values [56]. Similarly to Ca, phosphate $\left(\mathrm{PO}_{4}{ }^{3-}\right)$ is also essential for proper body development by sustaining the skeletal system. P deficiency results in reduced growth rates and bone mineralization, thus resulting in skeletal anomalies. Importantly, $\mathrm{Sr}$ ingestion seems to cause a decreased assimilation of both $\mathrm{Ca}$ and $\mathrm{P}$; hence, the values of $\mathrm{Ca} / \mathrm{Sr}$ and $\mathrm{PO}_{4}{ }^{3-} / \mathrm{Sr}$ ratios are in some way related [56].

In several laboratories, the search of materials (as a vehicle for $\mathrm{Sr}$ ) displaying low cellular toxicity, even better showing synergistic activity in promoting regeneration of bone tissue, is highly active. In this regard, a composite of $\mathrm{Sr}$ and Ca polyphosphate (CPP) was described showing excellent mechanical properties with a steady release of $\mathrm{Ca}, \mathrm{PO}_{4}{ }^{3-}$, and $\mathrm{Sr}$ ions, which stimulates osteoblasts growth in vitro [58]. In animal models (in vivo), the composite behaves similarly as in vitro, e.g., in the canine femur, Sr-CPP composite promotes considerably bone formation and angiogenesis [59]. Similarly, Li et al. reported a composite consisting of Sr, hydroxyapatite (SrHA), and BisGMA, which showed satisfactory bioactivity $[60,61]$. Hernandez et al. developed a cement based on SrHA and poly(methyl methacrylate) intended to be used in minimally invasive surgeries, this composite showed excellent bioactivity in vitro and thus, potential use in vivo. Notably, high biocompatibility is observed in the above composites, which is characterized by low cytotoxicity and improved cell proliferation of fibroblast cultures [62].

Therefore, Sr promotes cell proliferation and differentiation, as well as mineralization. Nonetheless, Sr behavior seem to depend to the anion to which it is conjugated [46]; for example, it has been used in combination with ranelate (SrRA) in bone regeneration therapy [63]. The salt has been indicated in postmenopausal osteoporosis treatment showing effects also on cartilage and subchondral bone. Preclinical studies performed indicate that SrRA inhibits subchondral bone resorption and 
promotes formation of the cartilage matrix in human chondrocytes, both in normal and osteoarthritic conditions [63]. SrRA induces the maturation of osteoblastic cells and increases the synthesis of collagen and non-collagen proteins. Regarding other effects of SrRA in bone formation, reports have shown that it also improves the preosteoblastic cellular replication [64]. However, the use of SrRA is being reviewed currently because of the increased incidence of cardiac failure events and thromboembolism [18], while other important risks have also been reported, namely cutaneous adverse reactions, alterations of consciousness, seizures, hepatitis, and cytopenia (European Medicines Agency, 2011). Therefore, the unfavorable benefit-risk balance for Sr ranelate is clear; as consequence, marketing authorization for pharmaceutical products (Protelos ${ }^{\circledR}$ and Osseor ${ }^{\circledR}$ ) containing SrRA has been suspended by the Pharmacovigilance Risk Assessment Committee (PRAC) of the European Medicines Agency (EMA). Furthermore, a safety alert on severe allergic reactions has been issued for drugs containing Sr ranelate (European Medicines Agency, 2011). In spite of that, others organic anions are being evaluated in order to improve the bioavailability of $\mathrm{Sr}$ and to avoid most of the disadvantages associated with the ranelic moiety [65].

Nonetheless, the development of bone replacement materials has continued to be an important goal in medicine, mainly because of the disadvantages in the use of bone autografts. In this regard, the intended use of $\mathrm{Sr}$ to this goal has not vanished and others composites have been tried, e.g., alginate hydrogels prepared with arginine-glycine-modified aspartic acid (RGD) cross-linked with $\mathrm{Sr}$ and $\mathrm{Zn}$ ions, and including $\mathrm{Ca} ; \mathrm{Zn}$ is required for alkaline phosphatase (ALP) activity. Although Ca and $\mathrm{Sr}$ based hydrogels display different stabilities during storage, they have similar stiffness and support the proliferation of osteoblast-like cells. Notably, the release of Sr from alginate gels is constant, sustained, and biologically active. Sr induces positive regulation of phenotypic marker genes in osteoblasts: RUNX2, collagen I (COL1A1) and bone sialoprotein (BSP), while ALP protein activity was maximal in alginate gels containing Sr. The strategy may be extensive to combination with other systems or to adaptation to applications in bone tissue engineering. It has been suggested that hydrogels may be used as a reservoir for the slow-release of Sr leading to improve osteogenic activity and/or differentiation [15]. Remarkably, studies showed that the effectiveness of Sr may be increased when in combination with other ions $[15,18]$.

During osteogenesis, multiple signaling pathways, including Vascular endothelial growth factor (VEGF), runt-related transcription factor 2 (Runx2), osterix (Osx), bone morphogenic protein (BMP), mitogen-activated protein kinase (MAPK), and the wingless-type MMTV integration site $(\mathrm{Wnt}) / \beta$-catenin pathways, regulate the proliferation and differentiation of osteoblasts, and hence are involved in controlling bone formation. In addition, the increased expression of bone matrix proteins, such as alkaline phosphatase (ALP), type I collagen (ColI), and osteopontin (OPN) also stimulate mineralization and bone formation [66]. Osteoblasts, besides regulates bone formation, also control bone resorption by modulating osteoclastogenesis via osteoprotegerin (OPG)/receptor activator of nuclear factor- $\kappa \mathrm{B}$ and ligand (RANKL)/receptor activator of nuclear factor- $\mathrm{B}$ (RANK) system [66,67].

Vascular endothelial growth factor (VEGF) is involved in angiogenesis and vascular homeostasis [68] and plays an essential role for regulating angiogenesis, endothelial cell function, and hence, signaling maturation of osteoblasts, ossification, and bone turnover. [69]. The angiogenic process accompanies bone regeneration acting as a limiting factor for the healing process [70]. Salinas et al. [71] showed a synergistic effect of VEGF adsorbed on silicon substituted hydroxyapatite scaffolds, resulting in more ossification, larger trabeculae and higher degree in angiogenesis [71]. Interestingly, incorporation of $\mathrm{Sr}$ in a fluorapatite glass-ceramics system leads to a highly ordered microstructure, increased solubility, and sustained Sr release, demonstrating that the in situ delivery of key elements is an attractive strategy to promote both angiogenesis and osteogenesis [10,72]. The fluorapatite-based glass composite sustained the release of $\mathrm{Sr}$ in vitro and in vivo, where the rate of mineral apposition is higher than the Sr undoped composite. Therefore, the efficiency of Sr in promoting osteoblastic activity is clear [10]. 
Among a series of GFs used in exogenous delivery strategies in bone repair, the bone morphogenetic proteins (such as BMP-2) are well known that promote osteoblastic differentiation of MSCs as well as the regeneration of bone at early phase of formation [73]. BMP-2 in conjunction with biochemical factors (chemical compounds, bioactive cytokines, and drugs) is known to synergistically promote osteogenesis, thus leading to bone regeneration under physiological microenvironment [74]. In example, some vitamins maintain body $\mathrm{Ca}$ and $\mathrm{PO}_{4}{ }^{3-}$ balance, while the drug dexamethasone (Dex) promotes osteogenic differentiation of MSCs in vitro [75,76]. Hence, a synergistic effect of BMP-2 and vitamin D3 in osteogenic differentiation of adipose derived stem cells (ADSCs) has been observed in vitro; a high dose of vitamin D3 upregulates ALP expression and mineralization of ADSCs. Additionally, studies have showed a controlled and sustained release of BMP-2 and Dex using engineered delivery platforms activating bone regenerative processes [73].

BMP-2 is known to induce or promote the expression of RUNX2; a transcription factor essential for osteoblast differentiation and bone formation [77]. Nonetheless, ALP, COL-1, and osteocalcin are also essential in osteoblast differentiation, thus also considered as molecular markers in bone formation [78]. BMP-2 regulates osteoblast differentiation by stimulating osteoblast-related transcription factors, such as RUNX2 and SMAD1, while the closely-related protein, SMAD5 mediates the responses to BMP-2 [73,76]. Bone morphogenetic proteins (BMP) are members of the TGF $\beta$ superfamily. These proteins have diverse functions in multiple developmental processes such as in embryogenesis, organogenesis, bone formation, cell proliferation, and stem cell differentiation [73].

Bone marrow MSC cultures, when exposed to Sr, displays a significant increase in the expression of the master gene, Runx2, and bone sialoprotein (BSP), which are associated to the increase of colony-forming unit osteoblasts. Interestingly, the $\mathrm{Sr}$ mediated activation of gene expression varies with differentiation stage of MSC; namely, Runx2 and BSP in bone marrow MSC, Runx2 and osteocalcin in preosteoblasts, and BSP and osteocalcin in mature osteoblasts [55].

\section{Role of Folic Acid and Vitamins $B_{6}$ and $B_{12}$ in Bone Regeneration}

Folate (FO) is a group of chemically complex substances of which the main role is to provide methyl groups in biosynthetic pathways. The human body is unable to synthesize FO; it is obtained from foods, and nowadays also in the form of dietary supplements. FO is essential at all ages in human life, from early development in the uterus to adulthood [79].

Biochemically, FO is a coenzyme that transfers carbon units necessary for the formation of deoxythymidylate used in the synthesis of purine and others methylation reactions. Therefore, folate is essential for cell division, embryonic and fetal development, and in the maintenance of cardiovascular and neurological functions. FO is produced by green plants, especially leafy vegetables, and some microorganisms, and it is found as a derivative of the reduced form of tetrahydrofolate (THF). Ingested FO becomes functional after intestinal absorption, distribution, transport into the cells, and biochemical modification. The lack of nutritional FO supplementation has been related to chronic pathologies such as cardiovascular disease, cancer, and cognitive dysfunction. Importantly, deficient nutritional status in maternal FO (Folic acid and FO derive from the aqueous soluble vitamin $\mathrm{B}_{9}$ ) is related to defects in the neural tube in offspring $[79,80]$. Therefore, folic acid supplementation during pregnancy is recommended by reproductive health epidemiological studies in different groups of women [81]. Nowadays, the consumption of probiotics is a new alternative to the supplementation of FO, e.g., strains of Bifidobacterium producing FO have been tested in humans and animals showing increasing levels of FO in plasma [82].

The effect of folic acid on bone turnover and bone metabolism has been evaluated [83,84]. Published results showed that folic acid supplementation does have beneficial effects on bone health status [85]. The effect of folic acid on bone metabolism and its turnover has been evaluated during pregnancy $[27,85]$. Results showed that pregnant women with daily folic acid $(1 \mathrm{mg})$ supplementation until the birth time display significant higher plasma levels in OPG concentration and lower in sRANKL concentration than pregnant women with folic acid supplementation up to the second 
trimester, consequently low rates in bone resorption is implied [85]. Importantly, better results are obtained when higher folic acid dose ( $5 \mathrm{mg} /$ day) is administered, i.e., the sRANKL/OPG ratio further decreases [27].

Inflammatory cytokines (IL-1, TNF, and M-CSF), which are released when osteoclastic bone is lost, stimulate RANKL production in osteoblast precursors and/or development of osteoblasts [86]. In contrast, these cytokines decrease OPG production through up-regulation of the RANK receptor in osteoclast precursors, thus increasing their sensitivity to normal RANKL concentrations [27,87]. In this regard, studies showed that $\mathrm{TNF} \alpha$ in serum decreases significantly during the administration of a high dose of folic acid. The TNF $\alpha$ decrease correlates with the decrease in sRANKL levels. Importantly, TNF $\alpha$ promotes osteoclastogenesis via RANKL system, i.e., by up-regulation of RANKL mRNA expression [88]. Therefore, in pregnant women folic acid supplementation in high dose decrease bone resorptive biomarkers by increasing OPG level and decreasing sRANKL and TNF $\alpha$ levels [27].

B-vitamins are a group of soluble vitamins that are cofactors of some of the enzymes involved in the metabolic pathways of carbohydrates, fats, and proteins; due to their promising properties, researchers have studied the advantages of their use in the clinical field, such as boosting the immune system [89]. B-vitamins are excellent adjuvants to achieve regeneration in several types of tissue. According to Fernández-Villa et al. folic acid derivatives are considered one of the most encouraging derivatives because they fulfill the requirements for their application in clinical use. It has been shown that these derivatives promote regenerative processes in a wide range of tissues and organs; further folic acid derivatives show a long lifespan under physiological conditions. This is the greatest limitation in regenerative therapies; e.g., when using growth factors or other recombinant proteins [90].

B-vitamin has also been linked to osteogenesis. An experimental study from Herman et al. showed a strong stimulation of human osteoclasts by the amino acid homocysteine (HCY) [91]. Other potential effects of HCY-related osteoporosis are reduced osteoblast activity [92] and disturbed extracellular collagen cross-linking [93]. It was proposed that the elevated HCY concentration in vivo is caused mainly by deficiencies in FO, vitamin B12 and B6, as they are directly involved in degradation of HCY. In a large series of experiments using cell cultures, Herrman et al. demonstrated the important role of FO and these B-vitamins in bone metabolism, namely FO, vitamin B12, and vitamin B6 stimulated osteoclast activity by accumulation of HCY [94]. In contrast, in preosteoblastic bone marrow cells, vitamin B12 increases alkaline phosphatase activity in a concentration-dependent way [91].

Likewise, folic acid and FO are important molecules in bone health; vitamin $\mathrm{B}_{9}$ derive from both molecules. The most prominent role of vitamin $\mathrm{B}_{9}$ is detoxification of HCY related to inflammation and to increased risk of fractures. Studies performed in developed countries showed that women (during menopause) experience a diminished ability to manage homocysteine adequately and that supplementation with folic acid improves the processing of homocysteine [95]. Nonetheless, this is not yet recognized as a universal [96].

Hyperhomocysteinemia seems to have a potential role in the development of osteoporosis. HCY is the aminoacid produced in methionine catabolism. Interestingly, serum concentration of HCY shows an inverse relationship with vitamin $B_{12}$ and folic acid [96]. HCY metabolism is related therefore to methionine concentration, expression of enzymes, concentrations of cofactors (vitamin $\mathrm{B}_{6}$ and $\mathrm{B}_{12}$ ), and FO (tetrahydrofolate production). Therefore, a deficiency in enzyme activity or the absence of cofactors may cause accumulation of HCY in cell cytoplasm, but also in blood plasma [97,98]. Importantly, studies have shown an association between high blood plasma HCY levels and osteoporotic fractures in elderly women and men [99]. The proposal that HCY plays a role in bone metabolism is supported by studies examining the relationship between a polymorphism in the methylene tetrahydrofolate reductase gene (MTHFR) and bone mineral density (BMD). However, the exact relationship between the level of HCY in plasma and BMD is uncertain. Methylation of HCY leads to form methionine in a reaction catalyzed by methionine synthase [100]. Methyl-tetrahydrofolate behaves as the donor of the methyl groups using vitamin $\mathrm{B}_{12}$ as a cofactor. Methyl-tetrahydrofolate is synthesized from folic acid, in a route where methylenetetrahydrofolate-reductase (MTHFR) participates using FAD 
(flavin-adenine-dinucleotide) as a cofactor. Therefore, four vitamins (folic acid, vitamin $\mathrm{B}_{6}$, vitamin $\mathrm{B}_{12}$, and riboflavin) participate in the metabolic reactions leading to decrease HCY levels. Deficiencies in these vitamins increase homocysteinemia, this in turn impact in bone mineral density [100].

A relationship between homocysteine levels and the incidence of fractures seems to exist in individuals [98,101]. However, no relationship has been found between homocysteine levels in plasma and density in bone mineral [101]. Nonetheless, other studies have shown that folic acid and vitamin $B_{12}$ deficiency is specifically associated with a decrease in BMD and a high incidence of fractures [102,103]. Since folic acid, vitamin $B_{12}$, and homocysteine are metabolically related, their specific influence in skeletal homeostasis becomes difficult to determine; however, when analyzed in conjunction, a statistically significant association is observed in the concentration of folic acid and vitamin $\mathrm{B}_{12}$ with BMD [100].

$\mathrm{BMD}$ and bone mineral content are known to be influenced by Vitamin $\mathrm{B}_{12}, \mathrm{Ca}$, and vitamin D. In this regard, studies in vitro show that vitamin $B_{12}$ does have a significant effect on osteoblasts proliferation, e.g., vitamin $B_{12}$ increases alkaline phosphatase activity in osteoclastic cells. A minute amount of vitamin $B_{12}$ is necessary to observe a positive effect on osteoblasts proliferation. In elderly patients, Dhonukshe-Rutten et al. found a relationship between vitamin $\mathrm{B}_{12}, \mathrm{BMD}$ and bone mineral content [104]. Therefore, as vitamin $B_{12}$ seems to be related to bone health, the treatment of vitamin $\mathrm{B}_{12}$ deficiency may help to prevent osteoporosis. Additional studies in elderly women showed an association between vitamin $B_{12}$ levels, its content in bone mineral, and BMD [104]. Therefore, the decrease or increase in vitamin $\mathrm{B}_{12}$ levels seems to be related to $\mathrm{BMD}$, and thus to the susceptibility or not to bone fractures, respectively. In agreement, the observed prevalence ratio in osteoporosis was higher in groups with deficient to marginal vitamin $B_{12}$ than those with normal levels. Studies suggest that clinical deficiency in vitamin $\mathrm{B}_{12}$ may be associated with poor functional maturation of osteoblasts and thus bone formation and resorption, respectively [91]. Vitamin $B_{12}$ participates as a cofactor in the transformation of homocysteine to methionine; however, the mechanism by which bone density is affected is not fully understood [96].

\section{Synthesis and Properties of SrFO}

Currently, the development of new osteogenic therapies is on clinical demand, namely in the treatment of osteoporosis and other bone diseases. The therapy based on Sr seems promising; nonetheless, any formulation should provide an effective and consistent way to deliver $\mathrm{Sr}$ ions with low or absence of secondary pharmacological effects. In this regard, Rojo et al. [18] developed a new strategy for Sr delivery based on FO as the carrier [18]. Experimental results showed the improvement in the regenerative capacity of skeletal tissues; thus evidencing a high efficiency of $\mathrm{Sr}$ as the active compound. Certainly, FO (the anionic form of folic acid) is a promising alternative as a $\mathrm{Sr}$ carrier in composites [18]. Additionally, the incorporation of B vitamins (folates) may contribute improving the metabolism and other processes in cells involved in bone regeneration [90].

$\mathrm{Ca}$ and SrFO complexes have been obtained and characterized physicochemically, and their bioactive properties in osteoporosis treatment have been evaluated (Figure 2) [18,58].

Sr folate ( $\mathrm{SrFO}$ ) shows low toxicity in vitro in human osteoblasts cultures and human mesenchymal Stem Cells, while inducing a significant expression of alkaline phosphatase (ALP) when compared to its $\mathrm{Ca}$ analogue (Figure 3). Studies suggest that SrFO could certainly display important therapeutic properties. Nonetheless, detailed analysis in $\mathrm{SrFO}$ physicochemical properties as well as the biological interaction with osteoblast and human stem cells have been conducted (Figure 4). 


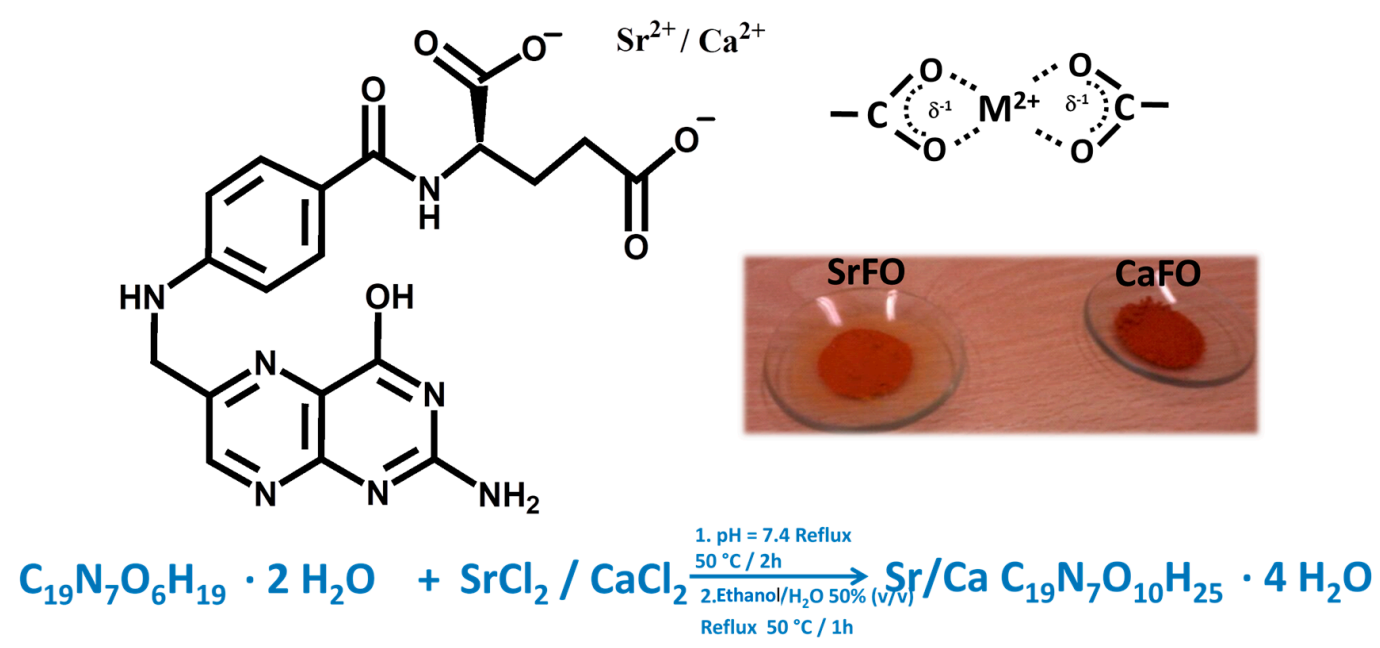

Figure 2. Chemical structure of calcium/strontium folic acid derivatives with bidentate coordination structure and synthetic conditions yielding pure powdered compounds. Figure adapted from Rojo et al. [18] with permission from the Royal society for Chemistry.

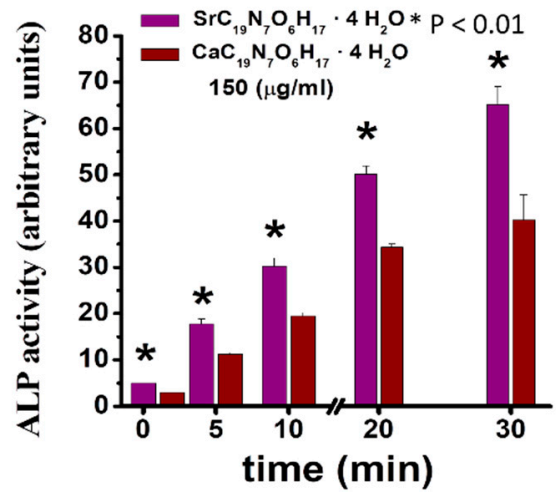

Figure 3. Alkaline phosphatase (ALP) expression in human osteoblasts cultured in the presence of $\mathrm{Sr}$ and Ca folic acid derivatives. Figure adapted from Rojo et al. [18] with permission from the Royal society for Chemistry.
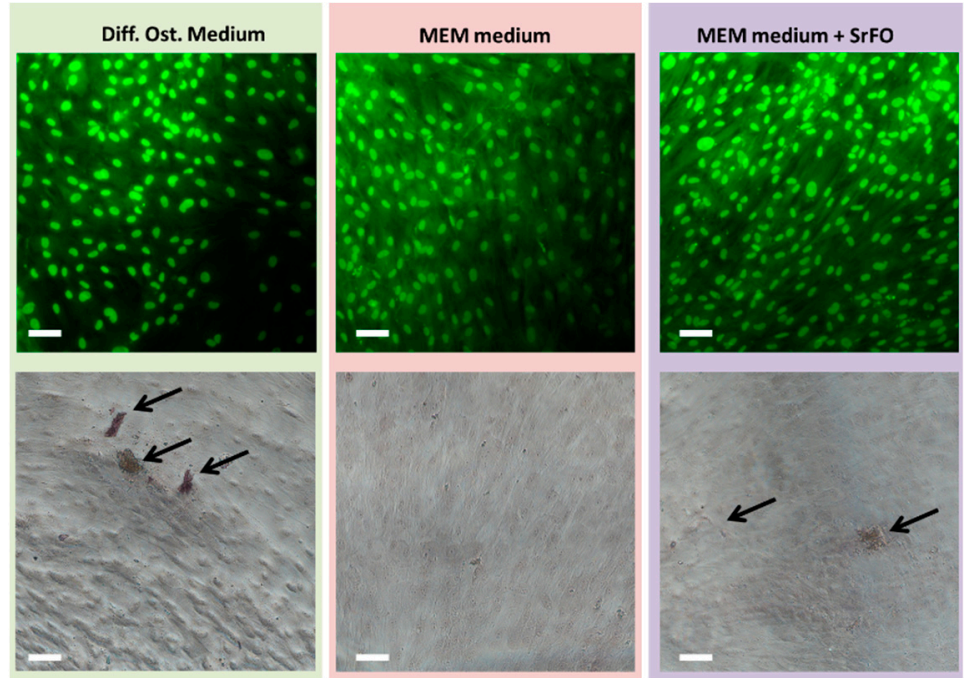

Figure 4. Acridine orange and propidium iodide (OA/PI) (upper) alizarin red (lower) staining of HMSC cultured for four days in osteogenic differentiation medium (left), MEM medium (center) and MEM + Strontium Folate (SrFO) (left). Arrows indicate deposits of calcified extracellular matrix. Scale bar = $100 \mu \mathrm{m}$ [105]. 
These studies would allow to state confidently its effect in bone regeneration, and consequently, its potential application in medical therapies, e.g., in chronic-degenerative bone diseases. Bioassays of $\mathrm{SrFO}$ and other chosen materials included in ceramic composites has been the subject of our laboratory, with the aim to develop a superior osteogenic scaffold behaving in a dual way, i.e., remodeling bone tissue by stimulating osteogenesis (cell proliferation) from dental pulp and by inhibiting bone resorption induced by osteolysis $[18,105]$.

\section{SrFO Loaded Biohybrid Scaffold Seeded with Dental Pulp Stem Cells as a New Composite System}

\subsection{Scaffolds Preparation Procedures and Characterization Techniques}

Increasing interest exist in biodegradable ceramic scaffolds for bone tissue engineering with the ability to deliver active molecules favoring bone formation. Denry et al. showed the action in vivo of strontium-containing glass-ceramic scaffolds, where Sr was successfully incorporated in the newly formed bone, thus increasing significantly the mineral apposition rate evidencing the benefits of in situ release of Sr [10]. Similarly, Tian et al. demonstrated the biocompatibility, osteogenesis (in vivo), and degradability of porous Sr-doped Ca polyphosphate scaffolds in bone substitute applications. Yang et al. [44] synthesized collagen-Sr-HA scaffold to evaluate the in vivo effects of $\mathrm{Sr}$ on bone formation [44]. Sr based systems are usually designed to serve as models for the manufacture of scaffolds. To date, only two studies do exist, which are the watersheds in the development of graft substitutes. Recently, Xu et al. tested titanium implants covered with $\mathrm{Sr}$ ions chelated with folic acid. The SrFO derivative was stable for long time, while minimal Sr ions release to body fluids. This device promoted the in vitro osteogenic differentiation of MSCs upon implantation. More recently, Martín-del-Campo et al. [16] prepared bioactive porous scaffolds by free radical polymerization of polyethylene glycol methacrylate in the presence of $\beta$-tricalcium phosphate (TCP) and SrFO as bioactive compounds (Figure 5) [16]. Roy and Bose tested in vitro the effects of Sr doping in $\beta$-TCP on differentiation of mononuclear cells into osteoclast-like cells and its resorptive activity, osteoclast-like cell formation, adhesion and resorption. Hence, substrate chemistry may control osteoclast differentiation and resorptive activity. Furthermore, it may be used for the design of TCP-based resorbable bone substitutes with controlled degradation and osteoclast-like cell formation activity [106].

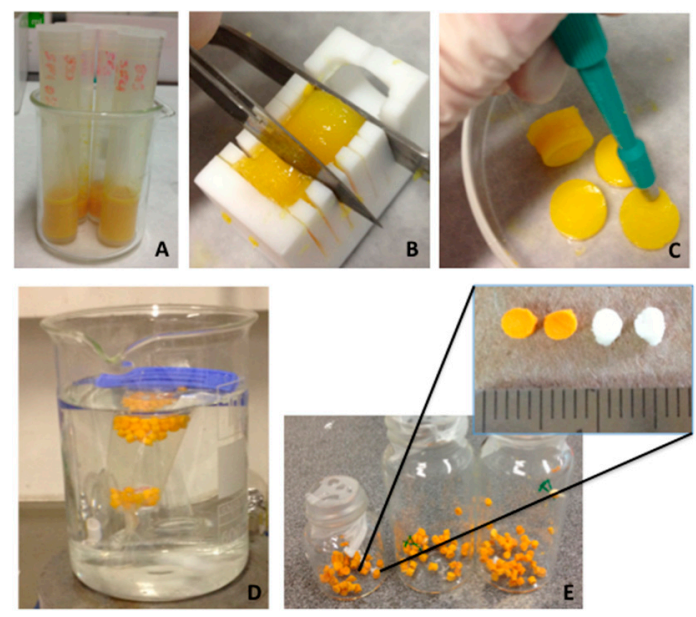

Figure 5. Procedure for scaffold construction as reported in Martin-del-Campo et al. (A) Solubilization and mixture of chemical components, (B) cutting to slices, (C) cutting with punch to obtain discs, (D) dialysis with membranes, and (E) final product (scaffold) [16].

Physical properties, morphology, distribution, size and interconnectivity of pores, and identification of component materials (mapping of elements) were studied in the SrFO loaded biohybrid scaffold by Martín-del-Campo et al. and by San Román et al. (Figure 6) $[16,107]$. The 
scaffolds are typically porous with a homogeneous structure and consistent cylindrical shape. Pores are homogeneously distributed displaying interconnected macropores $(>100 \mu \mathrm{m})$ and micropores $(<10 \mu \mathrm{m})$ [16]. The above are in agreement with previous studies, thus demonstrating that the presence of $\mathrm{Sr}$ in 3D biohybrid scaffolds does not influence the macro- and meso-porous structure in scaffolds. In addition, they provide proper dissolutions rates for $\mathrm{Ca}$ and $\mathrm{Sr}$ ions and exhibit an excellent microenvironment for cell viability, differentiation and osteogenic activity $[19,108,109]$. The mapping of elements in scaffolds were performed by energy-dispersive X-ray spectroscopy (EDS) in a scanning electron microscope (SEM) in order to determine the presence of TCP particles and SrFO (Ca and Sr elements respectively) and its dispersion in the matrix.

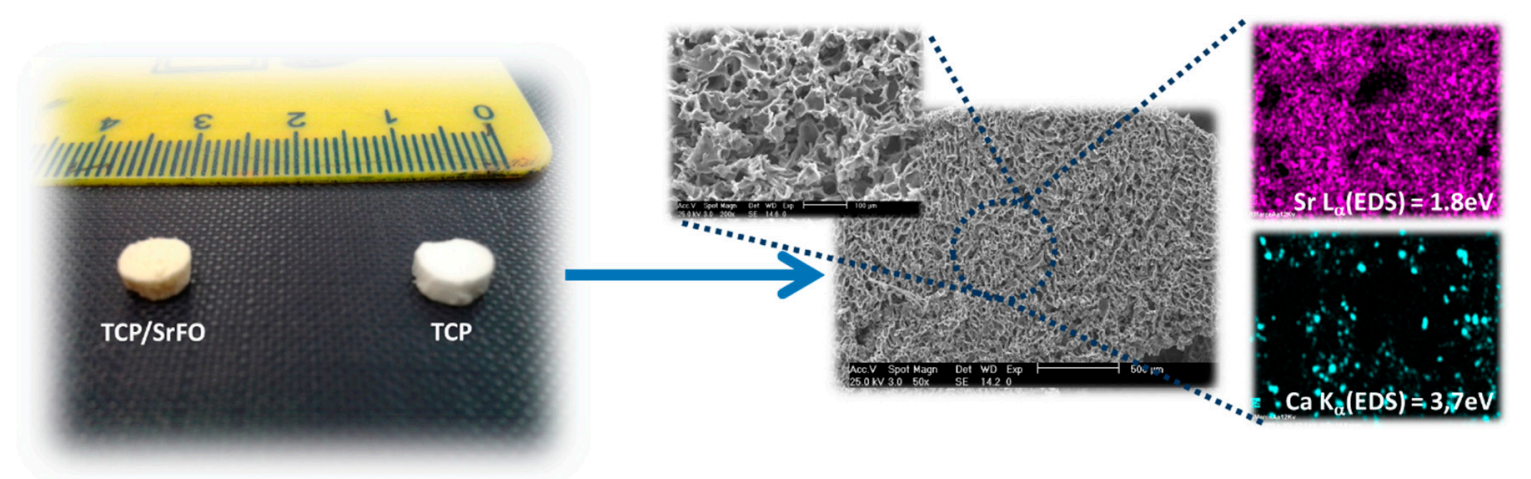

Figure 6. $\beta$-tricalcium phosphate (TCP) and $\mathrm{TCP} / \mathrm{SrFO}$ porous scaffolds obtained by free radical polymerization and lyophilization and surface analysis by scanning electron microscope (SEM) and energy-dispersive X-ray spectroscopy (EDS) spectroscopy [107].

The success of polymerization reaction, and absence of free monomers in TCP and TCP/Sr scaffolds were confirmed by Fourier transform infrared spectroscopy (ATR-FTIR) by the absence of the characteristic vinyl bands $(v)$ as $C=C$ at $1637 \mathrm{~cm}^{-1}$. The presence of a strong vibrating band at $1726 \mathrm{~cm}^{-1}$ corresponding to the carbonyl ester of the ceramic component was also discriminated from bands associated to phosphate groups (high and low intensity) observed in the region of 1000 to $500 \mathrm{~cm}^{-1}$ (Figure 7) [18].

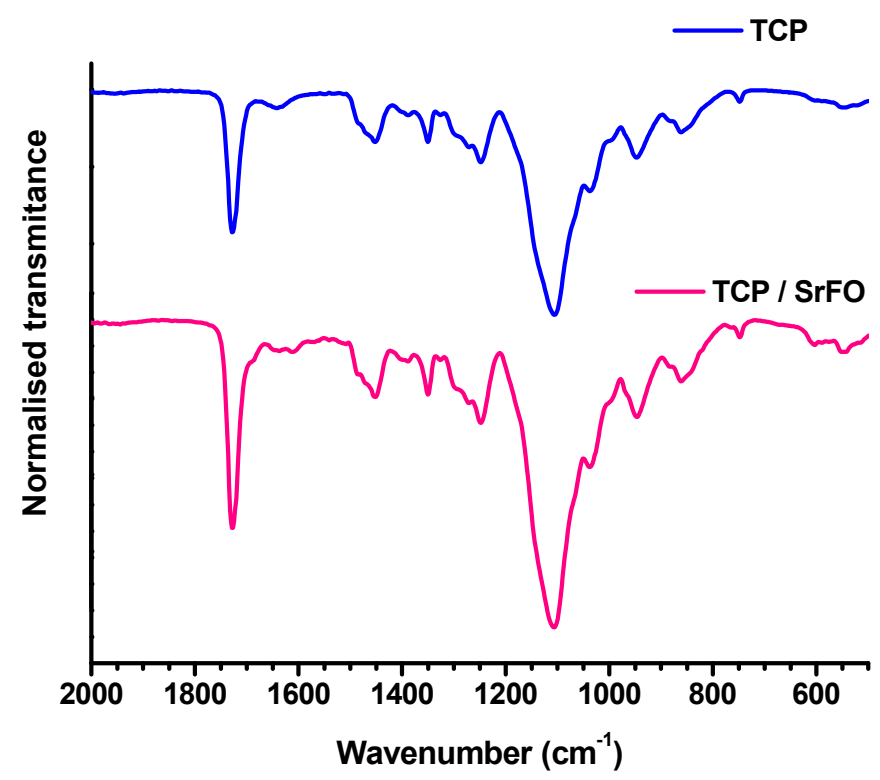

Figure 7. Surface analysis by FTIR-ATR spectroscopy of TCP and TCP/Sr scaffolds. Figure adapted from Martín-del-Campo et al. [16] with permission from the Royal society for Chemistry. 


\subsection{DPSC Viability on Scaffolds}

Studies suggest that incorporation of $\mathrm{Sr}$ ions in bone substitutes constitutes a safe and effective way to stimulate proliferation and differentiation of bone MSCs, osteoblasts, and periodontal ligament cells in vivo [19-21]. Recently, Martín-del-Campo et al. demonstrated that incorporation of SrFO into bio-hybrid scaffolds enhances the osteogenic differentiation of HDPSCs. That is, by performing cell culture and characterization of DPSCs, the HDPSCs phenotype and osteogenic profile were confirmed by immunoassays and the expression level of three osteogenic markers (RUNX-2, osteopontin, and osteocalcin), representative of middle and late stages of osteogenic differentiation, were determined histochemically (Figure 8) [16].

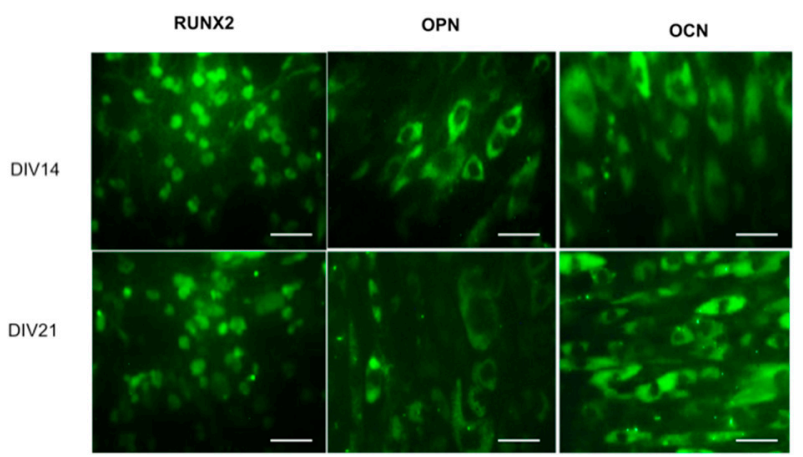

Figure 8. Differentiation of HDPSCs. Expression of RUNX-2, OPN, and OCN at days 14 and 21, (40× magnification). Scale bar $100 \mu \mathrm{m}$. Reproduced from Martín-del-Campo et al. [16], with permission from The Royal Society of Chemistry.

Cell viability and proliferation in composite scaffolds were confirmed, showing a large increase in cell population in TCP/SrFO group. After day seven, $\mathrm{H} \& \mathrm{E}$ viability assay showed a higher cell number in TCP/SrFO scaffolds than the TCP group (Figure 9). Xu et al. [17] confirmed that the high stability of Sr substrates improves cell proliferation in a long term resulting in a remarkably effect on viability of MSCs [17].

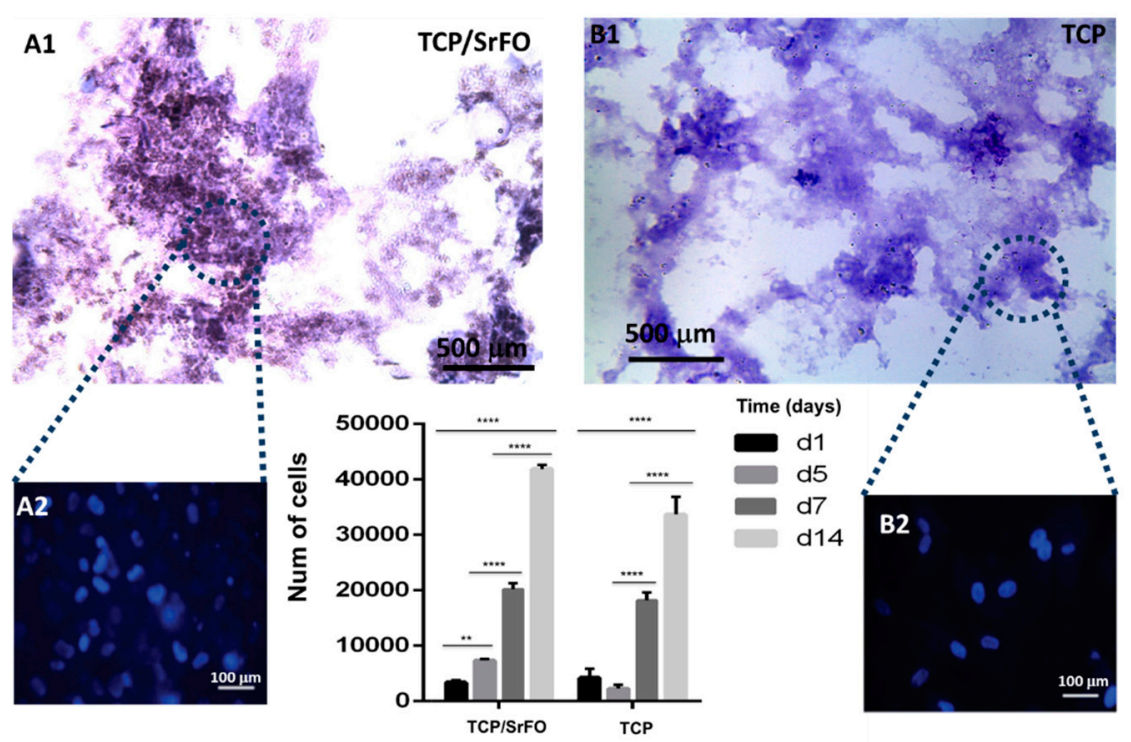

Figure 9. $\mathrm{H}$ \& $\mathrm{E}$ staining on sliced $\mathrm{TCP} / \mathrm{SrFO}$ (A1) and TCP (B1) scaffolds and nuclei staining (A2 and B2 respectively) of HDPSCs used for the viability quantification. Figure adapted from Martín-del-Campo et al. [16] with permission from The Royal Society of Chemistry. Stars show significant differences throughout days $*(p<0.0049){ }^{* * *}(p<0.0001){ }^{* * * *}(p<0.0001)$. 


\subsection{Rat Calvarial Defect Model and Implantation of the Scaffold}

Martín-del Campo et al. implemented a calvarial defect biomodel to perform the implantation of $\mathrm{SrFO} / \mathrm{TCP}$ scaffolds by filling completely the defective area (Figure 10).

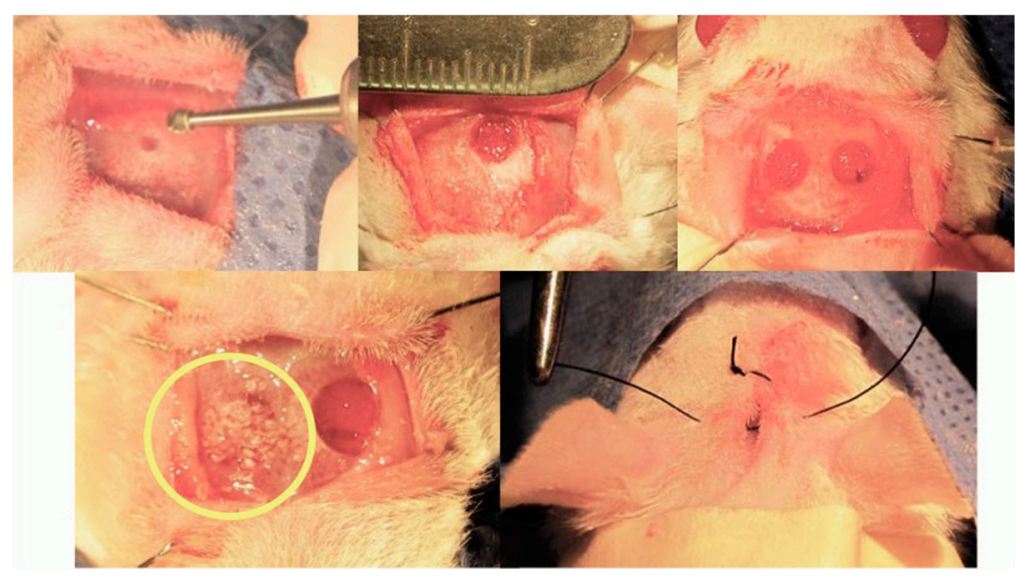

Figure 10. Implementation of the cranial defect model and construct (circle) transplantation. Process reported in Martín-del-Campo et al. [16].

The biomodels, after implantation of the constructs, showed good recovery and no signs of infection or inflammation as determined by Gross photographic examination and CT analysis. The implanted scaffolds resorb because of formation of newly mineralized tissue. Moreover, radiographic scans of ex vivo bone explant may evidence qualitatively and quantitatively the mineralized tissue in calvaria defects over time. The progressive healing (filling) of cavities is observed in both groups, which are characterized by mineralized tissue and moderate rates in bone growth. Remarkably, the density of the newly bone formed is higher in SrFO group compared with that in TCP (Figure 11) suggesting that $\mathrm{Sr}$ promoted the formation of new bone. Yang et al. [44] showed that in HA and Sr-containing scaffolds, the Ca phosphate based scaffold induces the formation of only some mature collagen fibers at the edges of the bone defect, while Sr-containing scaffold induces the formation of mature and remodeled bone at the boundary and in the central bone defect resulting in a relatively high bone density [44].

$\mathrm{H} \& \mathrm{E}$ staining of implants in the bio-model evidenced the formation of mature bone tissue in Sr-systems, displaying a highly organized laminar tissue and the absence of scaffolds remnants. Alizarin red stain when assayed at specific time intervals post-implantation displays the stages of mineralization of the newly formed tissue. In TCP/SrFO scaffolds implants a line like structures is observed indicating the start of mineralization and Ca organization, while osteocytes were observed in matrices indicating on site calcification. Von Kossa stain assay showed the start in calcification, after week 20th, the TCP/SrFO group shows the presence of organized mineralized tissue with the appearance of complete and mature bone. Mineralization is observed through cells and lamellar Ca deposits [16]. Xu et al. confirmed that $\mathrm{Sr}$ folic acid derivate may significantly enhance the ALP activity of MSCs in a short-time, and sustain an upregulated ALP activity for longer time. The mineralization of MSCs, as a late stage marker in osteogenic differentiation, demonstrates that $\mathrm{Sr}$ folic acid substrates promote MSCs osteogenic differentiation [17]. 

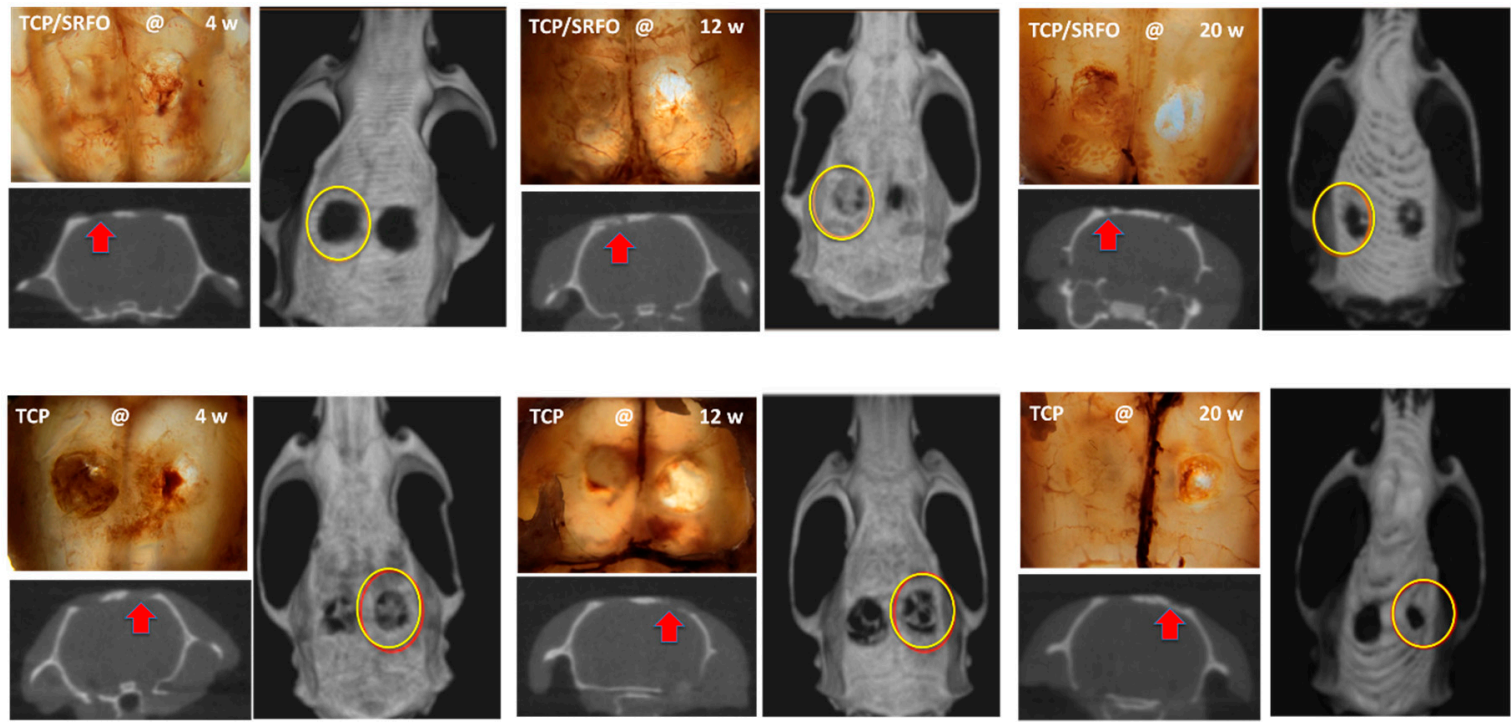

Figure 11. Healing evolution of treated cranial defects mediated by SrFO/TCP (upper) and TCP (lower) composite implants (circle or arrow) and without construct (control). Figure adapted from Martín-del-Campo et al. [16] with permission from The Royal Society of Chemistry.

\section{Perspectives and Conclusions}

SrFO based-scaffolds increase bone regeneration in vivo. The Sr-based-systems seem to be a useful alternative for the regeneration of bone tissue in complicated defects. Seeding with pluripotent stem cells increases its efficacy. This review provides an overview of the known knowledge for the design and manufacture of bio-hybrid scaffolds in tissue engineering combining the benefits of non-protein based morphogens $\mathrm{Sr}$ and B vitamins (folates), in combination with stem cells from dental pulp. Pluripotent cells from dental pulp could be considered an excellent alternative as a source of stem cells. Based on published experimental results, it is concluded that HDPSC seeded in hybrid scaffolds stimulates cell growth and differentiation. Furthermore, composite scaffolds containing SrFO are biocompatible and provide an excellent system in the regeneration of bone tissue. SrFO scaffold may be considered an option for the controlled release of Sr and Ca-phosphate. The device, when seeded with HDPSC, offers a potential alternative in the regeneration of bone tissue.

Author Contributions: L.R., M.M.-d.-C., J.G.S., M.L.F.-C. and R.R.-I. have contributed equally to this review article regarding conceptualization, methodology, formal analysis, Writing-Original Draft preparation, Writing-Review and Editing. L.R. and M.M.-d.-C. have supervised the editing and content of the manuscript while L.R. has contributed to funding acquisition.

Funding: This work was supported by the Spanish program MICINN (MAT201573656-JIN) and the Mexican programs CONACYT (711120) and UNAM-PAPIIT (IA209417).

Acknowledgments: L.R. wants to acknowledge Rosana Maria Ramirez (ICTP-CSIC) for her assistance obtaining Figure 4 .

Conflicts of Interest: The authors declare no conflict of interest.

\section{References}

1. Rojo, L. Combination of Polymeric Supports and Drug Delivery Systems for Osteochondral Regeneration. In Osteochondral Tissue Engineering; Oliveira, J.M., Pina, S., Reis, R.L., San Roman, J., Eds.; Springer International Publishing: Cham, Switzerland, 2018; Volume 1059, pp. 301-313. ISBN 978-3-319-76734-5.

2. Black, C.R.M.; Goriainov, V.; Gibbs, D.; Kanczler, J.; Tare, R.S.; Oreffo, R.O.C. Bone Tissue Engineering. Curr. Mol. Biol. Rep. 2015, 1, 132-140. [CrossRef] [PubMed]

3. Hutmacher, D.W.; Schantz, J.T.; Lam, C.X.F.; Tan, K.C.; Lim, T.C. State of the art and future directions of scaffold-based bone engineering from a biomaterials perspective. J. Tissue Eng. Regen. Med. 2007, 1, 245-260. [CrossRef] 
4. Ciraldo, F.E.; Boccardi, E.; Melli, V.; Westhauser, F.; Boccaccini, A.R. Tackling bioactive glass excessive in vitro bioreactivity: Preconditioning approaches for cell culture tests. Acta Biomater. 2018, 75, 3-10. [CrossRef]

5. Westhauser, F.; Höllig, M.; Reible, B.; Xiao, K.; Schmidmaier, G.; Moghaddam, A. Bone formation of human mesenchymal stem cells harvested from reaming debris is stimulated by low-dose bone morphogenetic protein-7 application in vivo. J. Orthop. 2016, 13, 404-408. [CrossRef] [PubMed]

6. Rosa, A.L.; de Oliveira, P.T.; Beloti, M.M. Macroporous scaffolds associated with cells to construct a hybrid biomaterial for bone tissue engineering. Expert Rev. Med. Devices 2008, 5, 719-728. [CrossRef]

7. Sachlos, E.; Czernuszka, J.T. Making tissue engineering scaffolds work. Review: The application of solid freeform fabrication technology to the production of tissue engineering scaffolds. Eur. Cell. Mater. 2003, 5, 29-39; discussion 39-40. [CrossRef] [PubMed]

8. Song, Z.; Yin, Z.; Li, C.; Yang, Z.; Ning, C.; Zhou, D.; Wang, R.; Xu, Y.; Qiu, J. Efficient and toxicity-free surface immobilization of nano-hydroxyapatite for bone-regenerative composite scaffolds by grafting polyvinyl pyrrolidone. Mater. Sci. Eng. C 2012, 32, 1032-1036. [CrossRef]

9. Hutmacher, D.W. Scaffolds in tissue engineering bone and cartilage. Biomaterials 2000, 21, $2529-2543$. [CrossRef]

10. Denry, I.; Goudouri, O.-M.; Fredericks, D.C.; Akkouch, A.; Acevedo, M.R.; Holloway, J.A. Strontium-releasing fluorapatite glass-ceramic scaffolds: Structural characterization and in vivo performance. Acta Biomater. 2018, 75, 463-471. [CrossRef] [PubMed]

11. Rojo, L.; Vázquez, B.; San Román, J. Biomaterials for scaffolds: Synthetic polymers. In Scaffolds for Tissue Engineering: Biological Design, Materials, and Fabrication, 1st ed.; Pan Stanford Publishing Pte. Ltd.: Singapore, 10 June 2014; pp. 263-300.

12. Bose, S.; Roy, M.; Bandyopadhyay, A. Recent advances in bone tissue engineering scaffolds. Trends Biotechnol. 2012, 30, 546-554. [CrossRef]

13. LeGeros, R.Z. Properties of osteoconductive biomaterials: Calcium phosphates. Clin. Orthop. 2002, 81-98. [CrossRef]

14. Jiménez, M.; Abradelo, C.; Román, J.S.; Rojo, L. Bibliographic review on the state of the art of strontium and zinc based regenerative therapies. Recent developments and clinical applications. J. Mater. Chem. B 2019, 7, 1974-1985. [CrossRef]

15. Place, E.S.; Rojo, L.; Gentleman, E.; Sardinha, J.P.; Stevens, M.M. Strontium- and zinc-alginate hydrogels for bone tissue engineering. Tissue Eng. Part A 2011, 17, 2713-2722. [CrossRef]

16. Martin-del-Campo, M.; Rosales-Ibañez, R.; Alvarado, K.; Sampedro, J.G.; Garcia-Sepulveda, C.A.; Deb, S.; San Román, J.; Rojo, L. Strontium folate loaded biohybrid scaffolds seeded with dental pulp stem cells induce in vivo bone regeneration in critical sized defects. Biomater. Sci. 2016, 4, 1596-1604. [CrossRef]

17. Xu, K.; Chen, W.; Mu, C.; Yu, Y.; Cai, K. Strontium folic acid derivative functionalized titanium surfaces for enhanced osteogenic differentiation of mesenchymal stem cells in vitro and bone formation in vivo. J. Mater. Chem. B 2017, 5, 6811-6826. [CrossRef]

18. Rojo, L.; Radley-Searle, S.; Fernandez-Gutierrez, M.; Rodriguez-Lorenzo, L.M.; Abradelo, C.; Deb, S.; Roman, J.S. The synthesis and characterisation of strontium and calcium folates with potential osteogenic activity. J. Mater. Chem. B 2015, 3, 2708-2713. [CrossRef]

19. Zhang, J.; Zhao, S.; Zhu, Y.; Huang, Y.; Zhu, M.; Tao, C.; Zhang, C. Three-dimensional printing of strontium-containing mesoporous bioactive glass scaffolds for bone regeneration. Acta Biomater. 2014, 10, 2269-2281. [CrossRef]

20. Liao, W.; Zhong, J.; Yu, J.; Xie, J.; Liu, Y.; Du, L.; Yang, S.; Liu, P.; Xu, J.; Wang, J.; et al. Therapeutic benefit of human umbilical cord derived mesenchymal stromal cells in intracerebral hemorrhage rat: Implications of anti-inflammation and angiogenesis. Cell. Physiol. Biochem. Int. J. Exp. Cell. Physiol. Biochem. Pharmacol. 2009, 24, 307-316. [CrossRef] [PubMed]

21. Caverzasio, J. Strontium ranelate promotes osteoblastic cell replication through at least two different mechanisms. Bone 2008, 42, 1131-1136. [CrossRef]

22. Marquez, L.; de Abreu, F.A.M.; Ferreira, C.L.; Alves, G.D.; Miziara, M.N.; Alves, J.B. Enhanced bone healing of rat tooth sockets after administration of epidermal growth factor (EGF) carried by liposome. Injury 2013, 44, 558-564. [CrossRef] [PubMed]

23. George, A.; Veis, A. Phosphorylated Proteins and Control over Apatite Nucleation, Crystal Growth, and Inhibition. Chem. Rev. 2008, 108, 4670-4693. [CrossRef] [PubMed] 
24. Zurick, K.M.; Qin, C.; Bernards, M.T. Adhesion of MC3T3-E1 cells bound to dentin phosphoprotein specifically bound to collagen type I. J. Biomed. Mater. Res. A 2012, 100, 2492-2498. [CrossRef]

25. Zurick, K.M.; Qin, C.; Bernards, M.T. Mineralization induction effects of osteopontin, bone sialoprotein, and dentin phosphoprotein on a biomimetic collagen substrate. J. Biomed. Mater. Res. A 2013, 101, 1571-1581. [CrossRef] [PubMed]

26. Lam, J.; Takeshita, S.; Barker, J.E.; Kanagawa, O.; Ross, F.P.; Teitelbaum, S.L. TNF-alpha induces osteoclastogenesis by direct stimulation of macrophages exposed to permissive levels of RANK ligand. J. Clin. Investig. 2000, 106, 1481-1488. [CrossRef] [PubMed]

27. Maroufi, N.F.; Ghorbanihaghjo, A.; Melli, M.S.; Vaezi, M.; MEHRABANI, Z.H.A.; Amirkhiz, M.B.; Rashtchizadeh, N. Effects of High and Low Doses of Folic Acid on the Soluble Receptor Activator of Nuclear Factor-kappa B Ligand/Osteoprotegerin Ratio during Pregnancy. Iran. J. Public Health 2017, 46, 517.

28. Boyce, B.F.; Xing, L. Functions of RANKL/RANK/OPG in bone modeling and remodeling. Arch. Biochem. Biophys. 2008, 473, 139-146. [CrossRef] [PubMed]

29. Hong, J.-S.; Santolaya-Forgas, J.; Romero, R.; Espinoza, J.; Gonçalves, L.F.; Kim, Y.M.; Edwin, S.; Yoon, B.H.; Nien, J.K.; Hassan, S.; et al. Maternal plasma osteoprotegerin concentration in normal pregnancy. Am. J. Obstet. Gynecol. 2005, 193, 1011-1015. [CrossRef]

30. Klejna, K.; Naumnik, B.; Gasowska, K.; Myśliwiec, M. OPG/RANK/RANKL signaling system and its significance in nephrology. Folia Histochem. Cytobiol. 2009, 47, 199-206. [CrossRef]

31. Naylor, K.E.; Rogers, A.; Fraser, R.B.; Hall, V.; Eastell, R.; Blumsohn, A. Serum osteoprotegerin as a determinant of bone metabolism in a longitudinal study of human pregnancy and lactation. J. Clin. Endocrinol. Metab. 2003, 88, 5361-5365. [CrossRef]

32. Uemura, H.; Yasui, T.; Kiyokawa, M.; Kuwahara, A.; Ikawa, H.; Matsuzaki, T.; Maegawa, M.; Furumoto, H.; Irahara, M. Serum osteoprotegerin/osteoclastogenesis-inhibitory factor during pregnancy and lactation and the relationship with calcium-regulating hormones and bone turnover markers. J. Endocrinol. 2002, 174, 353-359. [CrossRef] [PubMed]

33. Yano, K.; Shibata, O.; Mizuno, A.; Kobayashi, F.; Higashio, K.; Morinaga, T.; Tsuda, E. Immunological study on circulating murine osteoprotegerin/osteoclastogenesis inhibitory factor (OPG/OCIF): Possible role of OPG/OCIF in the prevention of osteoporosis in pregnancy. Biochem. Biophys. Res. Commun. 2001, 288, 217-224. [CrossRef]

34. Gronthos, S.; Mankani, M.; Brahim, J.; Robey, P.G.; Shi, S. Postnatal human dental pulp stem cells (DPSCs) in vitro and in vivo. Proc. Natl. Acad. Sci. USA 2000, 97, 13625-13630. [CrossRef]

35. Gronthos, S.; Brahim, J.; Li, W.; Fisher, L.W.; Cherman, N.; Boyde, A.; DenBesten, P.; Robey, P.G.; Shi, S. Stem cell properties of human dental pulp stem cells. J. Dent. Res. 2002, 81, 531-535. [CrossRef]

36. Gronthos, S.; Arthur, A.; Bartold, P.M.; Shi, S. A method to isolate and culture expand human dental pulp stem cells. Methods Mol. Biol. 2011, 698, 107-121.

37. Morito, A.; Kida, Y.; Suzuki, K.; Inoue, K.; Kuroda, N.; Gomi, K.; Arai, T.; Sato, T. Effects of basic fibroblast growth factor on the development of the stem cell properties of human dental pulp cells. Arch. Histol. Cytol. 2009, 72, 51-64. [CrossRef] [PubMed]

38. Kim, S.-H.; Kim, Y.-S.; Lee, S.-Y.; Kim, K.-H.; Lee, Y.-M.; Kim, W.-K.; Lee, Y.-K. Gene expression profile in mesenchymal stem cells derived from dental tissues and bone marrow. J. Periodontal Implant Sci. 2011, 41, 192-200. [CrossRef] [PubMed]

39. Laino, G.; d'Aquino, R.; Graziano, A.; Lanza, V.; Carinci, F.; Naro, F.; Pirozzi, G.; Papaccio, G. A new population of human adult dental pulp stem cells: A useful source of living autologous fibrous bone tissue (LAB). J. Bone Miner. Res. Off. J. Am. Soc. Bone Miner. Res. 2005, 20, 1394-1402. [CrossRef] [PubMed]

40. Yang, J.; Darley, R.L.; Hallett, M.; Evans, W.H. Low connexin channel-dependent intercellular communication in human adult hematopoietic progenitor/stem cells: Probing mechanisms of autologous stem cell therapy. Cell Commun. Adhes. 2009, 16, 138-145. [CrossRef] [PubMed]

41. El-Backly, R.M.; Massoud, A.G.; El-Badry, A.M.; Sherif, R.A.; Marei, M.K. Regeneration of dentine/pulp-like tissue using a dental pulp stem cell/poly(lactic-co-glycolic) acid scaffold construct in New Zealand white rabbits. Aust. Endod. J. 2008, 34, 52-67. [CrossRef]

42. Choudhary, S.; Halbout, P.; Alander, C.; Raisz, L.; Pilbeam, C. Strontium ranelate promotes osteoblastic differentiation and mineralization of murine bone marrow stromal cells: Involvement of prostaglandins. J. Bone Miner. Res. Off. J. Am. Soc. Bone Miner. Res. 2007, 22, 1002-1010. [CrossRef] 
43. Peng, S.; Liu, X.S.; Wang, T.; Li, Z.; Zhou, G.; Luk, K.D.K.; Guo, X.E.; Lu, W.W. In vivo anabolic effect of strontium on trabecular bone was associated with increased osteoblastogenesis of bone marrow stromal cells. J. Orthop. Res. Off. Publ. Orthop. Res. Soc. 2010, 28, 1208-1214. [CrossRef] [PubMed]

44. Yang, F.; Yang, D.; Tu, J.; Zheng, Q.; Cai, L.; Wang, L. Strontium enhances osteogenic differentiation of mesenchymal stem cells and in vivo bone formation by activating Wnt/catenin signaling. Stem Cells Dayt. Ohio 2011, 29, 981-991. [CrossRef]

45. Bruyere, O.; Roux, C.; Detilleux, J.; Slosman, D.O.; Spector, T.D.; Fardellone, P.; Brixen, K.; Devogelaer, J.-P.; Diaz-Curiel, M.; Albanese, C.; et al. Relationship between bone mineral density changes and fracture risk reduction in patients treated with strontium ranelate. J. Clin. Endocrinol. Metab. 2007, 92, 3076-3081. [CrossRef]

46. Fernández-Murga, M.L.; Serna, E.; Sanz-Salvador, L.; Hervás-Lorente, A.; Portero, J.; Cano, A. Response of osteoblasts to compounds of strontium or calcium: Proliferation, differentiation, mineralisation and whole genome response. Rev. Osteoporos. Metab. Miner. 2013, 5, 133-140. [CrossRef]

47. Fromigué, O.; Haÿ, E.; Barbara, A.; Marie, P.J. Essential role of nuclear factor of activated T cells (NFAT)-mediated Wnt signaling in osteoblast differentiation induced by strontium ranelate. J. Biol. Chem. 2010, 285, 25251-25258. [CrossRef]

48. Rybchyn, M.S.; Slater, M.; Conigrave, A.D.; Mason, R.S. An Akt-dependent increase in canonical Wnt signaling and a decrease in sclerostin protein levels are involved in strontium ranelate-induced osteogenic effects in human osteoblasts. J. Biol. Chem. 2011, 286, 23771-23779. [CrossRef]

49. Pasqualetti, S.; Banfi, G.; Mariotti, M. The zebrafish scale as model to study the bone mineralization process. J. Mol. Histol. 2012, 43, 589-595. [CrossRef]

50. Zarins, J.; Pilmane, M.; Sidhom, E.; Salma, I. Does Local Application of Strontium Increase Osteogenesis and Biomaterial Osteointegration in Osteoporotic and Other Bone Tissue Conditions: Review of Literature. Acta Chir. Latv. 2016, 16, 17-23. [CrossRef]

51. Zhang, Y.; Wei, L.; Chang, J.; Miron, R.J.; Shi, B.; Yi, S.; Wu, C. Strontium-incorporated mesoporous bioactive glass scaffolds stimulating in vitro proliferation and differentiation of bone marrow stromal cells and in vivo regeneration of osteoporotic bone defects. J. Mater. Chem. B 2013, 1, 5711-5722. [CrossRef]

52. Atkins, G.J.; Welldon, K.J.; Halbout, P.; Findlay, D.M. Strontium ranelate treatment of human primary osteoblasts promotes an osteocyte-like phenotype while eliciting an osteoprotegerin response. Osteoporos. Int. 2009, 20, 653-664. [CrossRef] [PubMed]

53. Bakker, A.D.; Zandieh-Doulabi, B.; Klein-Nulend, J. Strontium Ranelate affects signaling from mechanically-stimulated osteocytes towards osteoclasts and osteoblasts. Bone 2013, 53, 112-119. [CrossRef]

54. Cianferotti, L.; D'Asta, F.; Brandi, M.L. A review on strontium ranelate long-term antifracture efficacy in the treatment of postmenopausal osteoporosis. Ther. Adv. Musculoskelet. Dis. 2013, 5, 127-139. [CrossRef]

55. Tan, S.; Zhang, B.; Zhu, X.; Ao, P.; Guo, H.; Yi, W.; Zhou, G.-Q. Deregulation of bone forming cells in bone diseases and anabolic effects of strontium-containing agents and biomaterials. BioMed Res. Int. 2014, 2014, 814057. [CrossRef] [PubMed]

56. Polak-Juszczak, L. Impact of strontium on skeletal deformities in Baltic cod (Gadus morhua callaris L.). Chemosphere 2011, 83, 486-491. [CrossRef] [PubMed]

57. Szostek, K.; Głab, H.; Pudło, A. The use of strontium and barium analyses for the reconstruction of the diet of the early medieval coastal population of Gdańsk (Poland): A preliminary study. Homo Int. Z. Vgl. Forsch. Am Menschen 2009, 60, 359-372. [CrossRef] [PubMed]

58. Qiu, K.; Zhao, X.J.; Wan, C.X.; Zhao, C.S.; Chen, Y.W. Effect of strontium ions on the growth of ROS17/2.8 cells on porous calcium polyphosphate scaffolds. Biomaterials 2006, 27, 1277-1286. [CrossRef]

59. Chen, Y.W.; Shi, G.Q.; Ding, Y.L.; Yu, X.X.; Zhang, X.H.; Zhao, C.S.; Wan, C.X. In vitro study on the influence of strontium-doped calcium polyphosphate on the angiogenesis-related behaviors of HUVECs. J. Mater. Sci. Mater. Med. 2008, 19, 2655-2662. [CrossRef] [PubMed]

60. Ni, G.X.; Chiu, K.Y.; Lu, W.W.; Wang, Y.; Zhang, Y.G.; Hao, L.B.; Li, Z.Y.; Lam, W.M.; Lu, S.B.; Luk, K.D.K. Strontium-containing hydroxyapatite bioactive bone cement in revision hip arthroplasty. Biomaterials 2006, 27, 4348-4355. [CrossRef] [PubMed]

61. Li, Y.W.; Leong, J.C.; Lu, W.W.; Luk, K.D.; Cheung, K.M.; Chiu, K.Y.; Chow, S.P. A novel injectable bioactive bone cement for spinal surgery: A developmental and preclinical study. J. Biomed. Mater. Res. 2000, 52, 164-170. [CrossRef] 
62. Hernández, L.; Gurruchaga, M.; Goñi, I. Injectable acrylic bone cements for vertebroplasty based on a radiopaque hydroxyapatite. Formulation and rheological behaviour. J. Mater. Sci. Mater. Med. 2009, 20, 89-97. [CrossRef] [PubMed]

63. Reginster, J.-Y.; Badurski, J.; Bellamy, N.; Bensen, W.; Chapurlat, R.; Chevalier, X.; Christiansen, C.; Genant, H.; Navarro, F.; Nasonov, E.; et al. Efficacy and safety of strontium ranelate in the treatment of knee osteoarthritis: Results of a double-blind, randomised placebo-controlled trial. Ann. Rheum. Dis. 2013, 72, 179-186. [CrossRef]

64. Reginster, J.-Y.; Lecart, M.-P.; Deroisy, R.; Lousberg, C. Strontium ranelate: A new paradigm in the treatment of osteoporosis. Expert Opin. Investig. Drugs 2004, 13, 857-864. [CrossRef]

65. Bergamini, P.; Marchesi, E.; Pagnoni, A.; Lambertini, E.; Franceschetti, T.; Penolazzi, L.; Piva, R. Synthesis, characterization of strontium-bile acid salts and their bioactivity vs. the anti-osteoporosis drug strontium ranelate. J. Inorg. Biochem. 2009, 103, 891-897. [CrossRef]

66. Shin, H.D.; Yang, K.J.; Park, B.R.; Son, C.W.; Jang, H.J.; Ku, S.K. Antiosteoporotic effect of Polycan, beta-glucan from Aureobasidium, in ovariectomized osteoporotic mice. Nutr. Burbank Los Angel. Cty. Calif 2007, 23, 853-860. [CrossRef] [PubMed]

67. Yodthong, T.; Kedjarune-Leggat, U.; Smythe, C.; Wititsuwannakul, R.; Pitakpornpreecha, T. 1-Quebrachitol Promotes the Proliferation, Differentiation, and Mineralization of MC3T3-E1 Cells: Involvement of the BMP-2/Runx2/MAPK/Wnt/ $\beta$-Catenin Signaling Pathway. Molecules 2018, 23. [CrossRef] [PubMed]

68. Fox, S.B.; Gasparini, G.; Harris, A.L. Angiogenesis: Pathological, prognostic, and growth-factor pathways and their link to trial design and anticancer drugs. Lancet Oncol. 2001, 2, 278-289. [CrossRef]

69. Ferrara, N.; Gerber, H.-P.; LeCouter, J. The biology of VEGF and its receptors. Nat. Med. 2003, 9, 669-676. [CrossRef]

70. Rozen, N.; Bick, T.; Bajayo, A.; Shamian, B.; Schrift-Tzadok, M.; Gabet, Y.; Yayon, A.; Bab, I.; Soudry, M.; Lewinson, D. Transplanted blood-derived endothelial progenitor cells (EPC) enhance bridging of sheep tibia critical size defects. Bone 2009, 45, 918-924. [CrossRef]

71. Salinas, A.J.; Blanco-Bécares, J.M.; Mersinlioglu, O.; Casarrubios, L.; Fernández-Villa, D.; Feito, M.J.; Portolés, T.; González, B.; Vallet-Regí, M. Synthesis, Characterization and Biocompatibility of Mesolamellar Calcium Phosphate Hybrids Prepared by Anionic Surfactant Templating. ChemistrySelect 2018, 3, 6880-6891. [CrossRef]

72. Denry, I.; Holloway, J.A. Low temperature sintering of fluorapatite glass-ceramics. Dent. Mater. 2014, 30, 112-121. [CrossRef]

73. Choi, H.; Kim, G.-J.; Yoo, H.-S.; Song, D.; Chung, K.-H.; Lee, K.-J.; Koo, Y.; An, J. Vitamin C Activates Osteoblastogenesis and Inhibits Osteoclastogenesis via Wnt/ $\beta$-Catenin/ATF4 Signaling Pathways. Nutrients 2019, 11, 506. [CrossRef]

74. Park, J.-K.; Lee, E.-M.; Kim, A.-Y.; Lee, E.-J.; Min, C.-W.; Kang, K.-K.; Lee, M.-M.; Jeong, K.-S. Vitamin C deficiency accelerates bone loss inducing an increase in PPAR- $\gamma$ expression in SMP30 knockout mice. Int. J. Exp. Pathol. 2012, 93, 332-340. [CrossRef] [PubMed]

75. Koide, M.; Kobayashi, Y.; Yamashita, T.; Uehara, S.; Nakamura, M.; Hiraoka, B.Y.; Ozaki, Y.; Iimura, T.; Yasuda, H.; Takahashi, N.; et al. Bone Formation Is Coupled to Resorption Via Suppression of Sclerostin Expression by Osteoclasts. J. Bone Miner. Res. Off. J. Am. Soc. Bone Miner. Res. 2017, 32, 2074-2086. [CrossRef] [PubMed]

76. Lemonnier, J.; Ghayor, C.; Guicheux, J.; Caverzasio, J. Protein kinase C-independent activation of protein kinase D is involved in BMP-2-induced activation of stress mitogen-activated protein kinases JNK and p38 and osteoblastic cell differentiation. J. Biol. Chem. 2004, 279, 259-264. [CrossRef] [PubMed]

77. Kim, S.; Lee, S.; Kim, K. Bone Tissue Engineering Strategies in Co-Delivery of Bone Morphogenetic Protein-2 and Biochemical Signaling Factors. In Cutting-Edge Enabling Technologies for Regenerative Medicine; Chun, H.J., Park, C.H., Kwon, I.K., Khang, G., Eds.; Springer: Singapore, 2018; pp. 233-244, ISBN 9789811309502.

78. Nakashima, K.; Zhou, X.; Kunkel, G.; Zhang, Z.; Deng, J.M.; Behringer, R.R.; Crombrugghe, B. de The Novel Zinc Finger-Containing Transcription Factor Osterix Is Required for Osteoblast Differentiation and Bone Formation. Cell 2002, 108, 17-29. [CrossRef]

79. Blom, H.J.; Smulders, Y. Overview of homocysteine and folate metabolism. With special references to cardiovascular disease and neural tube defects. J. Inherit. Metab. Dis. 2011, 34, 75-81. [CrossRef]

80. Ebara, S. Nutritional role of folate. Congenit. Anom. 2017, 57, 138-141. [CrossRef] 
81. Barua, S.; Kuizon, S.; Junaid, M.A. Folic acid supplementation in pregnancy and implications in health and disease. J. Biomed. Sci. 2014, 21, 77. [CrossRef] [PubMed]

82. Rossi, M.; Amaretti, A.; Raimondi, S. Folate Production by Probiotic Bacteria. Nutrients 2011, 3, 118-134. [CrossRef]

83. Morris, M.S.; Jacques, P.F.; Selhub, J. Relation between homocysteine and B-vitamin status indicators and bone mineral density in older Americans. Bone 2005, 37, 234-242. [CrossRef]

84. Xian, C.J.; Cool, J.C.; Scherer, M.A.; Fan, C.; Foster, B.K. Folinic acid attenuates methotrexate chemotherapy-induced damages on bone growth mechanisms and pools of bone marrow stromal cells. J. Cell. Physiol. 2008, 214, 777-785. [CrossRef]

85. Hossein-Nezhad, A.; Mirzaei, K.; Maghbooli, Z.; Najmafshar, A.; Larijani, B. The influence of folic acid supplementation on maternal and fetal bone turnover. J. Bone Miner. Metab. 2011, 29, 186-192. [CrossRef]

86. Wei, S.; Kitaura, H.; Zhou, P.; Ross, F.P.; Teitelbaum, S.L. IL-1 mediates TNF-induced osteoclastogenesis. J. Clin. Investig. 2005, 115, 282-290. [CrossRef] [PubMed]

87. Weitzmann, M.N. The Role of Inflammatory Cytokines, the RANKL/OPG Axis, and the Immunoskeletal Interface in Physiological Bone Turnover and Osteoporosis. Available online: https:/www.hindawi.com/ journals/scientifica/2013/125705/ (accessed on 22 October 2018).

88. Zhang, Y.H.; Heulsmann, A.; Tondravi, M.M.; Mukherjee, A.; Abu-Amer, Y. Tumor necrosis factor-alpha (TNF) stimulates RANKL-induced osteoclastogenesis via coupling of TNF type 1 receptor and RANK signaling pathways. J. Biol. Chem. 2001, 276, 563-568. [CrossRef]

89. Lewicki, S.; Lewicka, A.; Kalicki, B.; Kłos, A.; Bertrandt, J.; Zdanowski, R. The influence of vitamin B12 supplementation on the level of white blood cells and lymphocytes phenotype in rats fed a low-protein diet. Cent. Eur. J. Immunol. 2014, 39, 419-425. [CrossRef] [PubMed]

90. Fernández-Villa, D.; Jiménez Gómez-Lavín, M.; Abradelo, C.; San Román, J.; Rojo, L. Tissue Engineering Therapies Based on Folic Acid and Other Vitamin B Derivatives. Functional Mechanisms and Current Applications in Regenerative Medicine. Int. J. Mol. Sci. 2018, 19. [CrossRef]

91. Herrmann, M.; Schmidt, J.; Umanskaya, N.; Colaianni, G.; Al Marrawi, F.; Widmann, T.; Zallone, A.; Wildemann, B.; Herrmann, W. Stimulation of osteoclast activity by low B-vitamin concentrations. Bone 2007, 41, 584-591. [CrossRef]

92. Hodgson, S.F.; Watts, N.B.; Bilezikian, J.P.; Clarke, B.L.; Gray, T.K.; Harris, D.W.; Johnston, C.C.; Kleerekoper, M.; Lindsay, R.; Luckey, M.M.; et al. American Association of Clinical Endocrinologists medical guidelines for clinical practice for the prevention and treatment of postmenopausal osteoporosis: 2001 edition, with selected updates for 2003. Endocr. Pract. Off. J. Am. Coll. Endocrinol. Am. Assoc. Clin. Endocrinol. 2003, 9, 544-564.

93. Bainbridge, K.E.; Sowers, M.; Lin, X.; Harlow, S.D. Risk factors for low bone mineral density and the 6-year rate of bone loss among premenopausal and perimenopausal women. Osteoporos. Int. 2004, 15, 439-446. [CrossRef] [PubMed]

94. Herrmann, M.; Widmann, T.; Colaianni, G.; Colucci, S.; Zallone, A.; Herrmann, W. Increased osteoclast activity in the presence of increased homocysteine concentrations. Clin. Chem. 2005, 51, 2348-2353. [CrossRef] [PubMed]

95. Salari, P.; Abdollahi, M. Controversial effects of non-steroidal anti-inflammatory drugs on bone: A review. Inflamm. Allergy Drug Targets 2009, 8, 169-175. [CrossRef] [PubMed]

96. Salari, P.; Abdollahi, M.; Heshmat, R.; Meybodi, H.A.; Razi, F. Effect of folic acid on bone metabolism: A randomized double blind clinical trial in postmenopausal osteoporotic women. Daru J. Fac. Pharm. Tehran Univ. Med. Sci. 2014, 22, 62. [CrossRef]

97. Cashman, K.D. Homocysteine and osteoporotic fracture risk: A potential role for B vitamins. Nutr. Rev. 2005, 63, 29-36. [CrossRef] [PubMed]

98. McLean, R.R.; Jacques, P.F.; Selhub, J.; Fredman, L.; Tucker, K.L.; Samelson, E.J.; Kiel, D.P.; Cupples, L.A.; Hannan, M.T. Plasma B Vitamins, Homocysteine, and Their Relation with Bone Loss and Hip Fracture in Elderly Men and Women. J. Clin. Endocrinol. Metab. 2008, 93, 2206-2212. [CrossRef] [PubMed]

99. Fratoni, V.; Brandi, M.L. B Vitamins, Homocysteine and Bone Health. Nutrients 2015, 7, 2176-2192. [CrossRef]

100. Riancho, J.A. Homocisteø ena, vitaminas y masa sea. Rev. Esp. Enfermedades Metabólicas Óseas 2006, 15, 85-87. [CrossRef] 
101. Van Meurs, J.B.J.; Dhonukshe-Rutten, R.A.M.; Pluijm, S.M.F.; van der Klift, M.; de Jonge, R.; Lindemans, J.; de Groot, L.C.P.G.M.; Hofman, A.; Witteman, J.C.M.; van Leeuwen, J.P.T.M.; et al. Homocysteine levels and the risk of osteoporotic fracture. N. Engl. J. Med. 2004, 350, 2033-2041. [CrossRef] [PubMed]

102. Cagnacci, A.; Baldassari, F.; Rivolta, G.; Arangino, S.; Volpe, A. Relation of homocysteine, folate, and vitamin B12 to bone mineral density of postmenopausal women. Bone 2003, 33, 956-959. [CrossRef] [PubMed]

103. Golbahar, J.; Hamidi, A.; Aminzadeh, M.A.; Omrani, G.R. Association of plasma folate, plasma total homocysteine, but not methylenetetrahydrofolate reductase C667T polymorphism, with bone mineral density in postmenopausal Iranian women: A cross-sectional study. Bone 2004, 35, 760-765. [CrossRef] [PubMed]

104. Dhonukshe-Rutten, R.A.M.; Lips, M.; de Jong, N.; Chin, A.; Paw, M.J.M.; Hiddink, G.J.; van Dusseldorp, M.; De Groot, L.C.P.G.M.; van Staveren, W.A. Vitamin B-12 status is associated with bone mineral content and bone mineral density in frail elderly women but not in men. J. Nutr. 2003, 133, 801-807. [CrossRef]

105. Asensio, G.; Ramirez, R.; González, J.; Abrelo, C.; San Roman, J.; Rojo, L. Evaluation of folic acid derivatives and biomimetic scaffolds for osteochondral tissue engineering. In Proceedings of the Actas del XLI Congreso de la Sociedad Ibérica de Biomecánica y Biomateriales, Madrid, Spain, 18-19 October 2018.

106. Roy, M.; Bose, S. Osteoclastogenesis and osteoclastic resorption of tricalcium phosphate: Effect of strontium and magnesium doping. J. Biomed. Mater. Res. A 2012, 100, 2450-2461. [CrossRef] [PubMed]

107. San Roman, J.; Martin, M.; Rojo, L.; Rosales, R.; Deb, S. Biohybrid Scaffolds based on Polymers and Strontiun Salts for the Regeneration of Bone Tissue. Tissue Eng. Part A 2015, 21, S59.

108. Fong, E.L.S.; Chan, C.K.; Goodman, S.B. Stem cell homing in musculoskeletal injury. Biomaterials 2011, 32, 395-409. [CrossRef] [PubMed]

109. Weick, J.P.; Johnson, M.A.; Skroch, S.P.; Williams, J.C.; Deisseroth, K.; Zhang, S.-C. Functional control of transplantable human ESC-derived neurons via optogenetic targeting. Stem Cells Dayt. Ohio 2010, 28, 2008-2016. [CrossRef] [PubMed]

(C) 2019 by the authors. Licensee MDPI, Basel, Switzerland. This article is an open access article distributed under the terms and conditions of the Creative Commons Attribution (CC BY) license (http://creativecommons.org/licenses/by/4.0/). 